\title{
Novel functionalised imidazo-benzocrown ethers bearing a thiophene spacer as fluorimetric chemosensors for metal ion detection
}

\author{
Cátia. I. C. Esteves, Rosa M. F. Batista, M. Manuela M. Raposo, * Susana P. G. Costa \\ Centre of Chemistry, University of Minho, Campus of Gualtar, 4710-057 Braga, Portugal
}

\begin{abstract}
Novel phenylalanine derivatives bearing benzimidazole and crown ethers as coordinating/reporting units and thiophene as spacer unit were synthesized, and their evaluation as fluorimetric chemosensors was carried out in acetonitrile and acetonitrile/water solutions. 15-Crown5 benzimidazolyl phenylalanine methyl ester, 15-crown-5 thienylbenzimidazolyl phenylalanine methyl ester and 18-crown-6 thienylbenzimidazolyl phenylalanine methyl ester were tested for alkaline, alkaline-earth and transition metal ions (such as $\mathrm{Na}^{+}, \mathrm{Ca}^{2+}, \mathrm{Cd}^{2+}, \mathrm{Co}^{2+}, \mathrm{Cr}^{3+}, \mathrm{Cu}^{2+}, \mathrm{Fe}^{2+}, \mathrm{Fe}^{3+}$, $\mathrm{Hg}^{2+}, \mathrm{Ni}^{2+}, \mathrm{Pd}^{2+}$ and $\left.\mathrm{Zn}^{2+}\right)$. The different crown ether binding moieties as well as the electronic nature and the length of the $\pi$-bridge linked to the benzimidazole heterocycle allowed the fine tuning of the sensory properties as seen by spectrofluorimetric titrations. Therefore, 15-crown-5 benzimidazolyl phenylalanine methyl ester is a fluorimetric chemosensor, being selective and sensitive for $\mathrm{Cu}^{2+}$ and $\mathrm{Pd}^{2+}$ in aqueous solutions $\left(\mathrm{ACN} / \mathrm{H}_{2} \mathrm{O} ; 80: 20\right)$. On the other hand, the metal cation sensing properties displayed by 15-crown-5 thienylbenzimidazolyl phenylalanine methyl ester bearing an arylthienyl spacer showed that this is a promising candidate as fluorimetric chemosensor for $\mathrm{Fe}^{3+}, \mathrm{Pb}^{2+}$ and $\mathrm{Pd}^{2+}$ in acetonitrile solution.
\end{abstract}

\section{Introduction}

The development of artificial receptors for the recognition of ionic species is currently of great interest as highly selective anion or cation sensing is imperative for many areas, including environmental, biological, clinical, and waste management applications [1]. Fluorescent sensors have been recognized as indispensable tools for monitoring ions and biomolecules with high sensitivity in cells and tissues and their potential for progress can be explained by the distinct advantages offered by fluorescence detection in terms of sensitivity, selectivity, response time and local observation, etc.

Suitable fluorescent reporters must efficiently transduce a binding event into a measurable fluorescence signal, and imidazo-based fluorophores have received increasing attention due to their interesting optical properties. Benzimidazole and its derivatives have been studied in anion and cation 
recognition systems that display color changes or fluorescence quenching or enhancement upon binding [2].

Crown ethers occupy a special position among receptors and are widely used in the design of new chemosensors based on their unique ability to coordinate the cations of alkaline metals, along with their fairly high selectivity and accessibility. In addition to alkaline metals, crown ethers are also effective complexing reagents for alkaline-earth and transition metal ions [3].

It has been reported that the combination of thiophene units and crown ethers can modulate the sensory behavior in order to obtain selective $\mathrm{Hg}^{2+}, \mathrm{Pd}^{2+}$ or $\mathrm{Cu}^{2+}$ fluorescent chemosensors taking advantage of cooperative effects in solution for the simultaneous exploration of alkaline/alkaline earth ions in the presence of transition metal ions. The selective and sensitive detection of these heavy or transition metal cations is also an interesting goal due to their importance in environmental and medicinal areas [4].

The design of ditopic chemosensors that contain two different binding sites capable of analysing multiple analytes simultaneously is a new and emerging topical field of supramolecular chemistry [5]. For the construction of fluorophore-labelled peptides and proteins, the insertion of suitable heterocyclic systems at the side chain of natural amino acids, as in the present case the introduction of a fused imidazole in a phenylalanine skeleton, can add extra functionality to the amino acid resulting in the development of functional unnatural amino acids possessing additional properties, such as increased UV absorption and fluorescence. UV-active amino acids are, therefore, valuable tools for biochemistry, cellular biology and cellular imaging applications.

Having these facts in mind, and following our research interests that include the synthesis and evaluation of fluorimetric chemosensors for anions and cations based on heterocycles and amino acids [6], new imidazo-benzocrown ether functionalised amino acids $\mathbf{3}$ and $\mathbf{4}$ were synthesized and their evaluation as fluorescent chemosensors is now reported. The different $\pi$-bridges linked to the benzimidazole coordinating/reporting unit are intended to improve the intramolecular electron delocalization, which will tune the photophysical properties of new sensors and optimize the recognition of target analytes through a greater sensitivity of fluorescence. Additionally, the introduction of different crown ether moieties is intended to improve the selectivity for the recognition of the targets.

\section{Experimental}

All melting points were measured on a Stuart SMP3 melting point apparatus. TLC analyses were carried out on $0.25 \mathrm{~mm}$ thick precoated silica plates (Merck Fertigplatten Kieselgel $60 \mathrm{~F}_{254}$ ) and spots were visualised under UV light. Chromatography on silica gel was carried out on Merck Kieselgel 
(230-240 mesh). NMR spectra were obtained on a Bruker Avance III 400 at an operating frequency of $400 \mathrm{MHz}$ for ${ }^{1} \mathrm{H}$ and $100.6 \mathrm{MHz}$ for ${ }^{13} \mathrm{C}$ using the solvent peak as internal reference at $25{ }^{\circ} \mathrm{C}$. All chemical shifts are given in ppm using $\delta_{\mathrm{H}} \mathrm{Me}_{4} \mathrm{Si}=0 \mathrm{ppm}$ as reference and $J$ values are given in $\mathrm{Hz}$. Assignments were made by chemical shifts, peak multiplicities and $J$ values and were supported by spin decoupling-double resonance and bidimensional heteronuclear correlation techniques. Low and high resolution mass spectrometry analyses were performed at the "C.A.C.T.I. - Unidad de Espectrometria de Masas", at University of Vigo, Spain. Fluorescence spectra were collected using a FluoroMax-4 spectrofluorometer. UV-visible absorption spectra (200-700 nm) were obtained using a Shimadzu UV/2501PC spectrophotometer. Luminescence quantum yields were measured using 9,10diphenylanthracene in ethanol as standard $\left(\Phi_{\mathrm{F}}=0.95\right)$ [7]. All commercially available reagents were purchased from Sigma-Aldrich, ACROS, or TCI and used as received. Organic solvents used in the spectroscopic studies were of spectroscopic grade. Compound 1a was synthesised as reported elsewhere [8] and $N$-(tert-butyloxycarbonyl)-4-bromo-L-phenylalanine methyl ester (the precursor for 1b) was prepared from commercially available 4-bromo-L-phenylalanine by standard protecting group chemistry.

\subsection{Synthesis of $N$-(tert-butyloxycarbonyl)-4-(5'-formylthiophen-2'-yl)-L-phenylalanine methyl ester, 1b}

$N$-(tert-Butyloxycarbonyl)-4-bromo-L-phenylalanine methyl ester $\left(0.170 \mathrm{~g}, 0.47 \times 10^{-3} \mathrm{~mol}, 1\right.$ equiv) and $\mathrm{Pd}\left(\mathrm{PPH}_{3}\right)_{4}\left(0.016 \mathrm{~g}, 0.014 \times 10^{-3} \mathrm{~mol}, 0.03\right.$ equiv) were stirred in DME $(10 \mathrm{~mL})$ during $10 \mathrm{~min}$ under inert atmosphere at $80^{\circ} \mathrm{C}$. 5-Formylthiophene boronic acid $\left(0.088 \mathrm{~g}, 0.57 \times 10^{-3} \mathrm{~mol}, 1.2 \mathrm{equiv}\right)$, dissolved in absolute ethanol $(1 \mathrm{~mL})$, and $\mathrm{Na}_{2} \mathrm{CO}_{3} 2 \mathrm{M}(0.5 \mathrm{~mL}, 2$ equiv) were added to the previous reaction mixture under inert atmosphere and the progress of the reaction was followed by TLC. Ethyl acetate $(10 \mathrm{~mL})$ and saturated $\mathrm{NaCl}$ solution $(10 \mathrm{~mL})$ were added, the mixture was transferred to an extraction funnel and the layers were separated. The organic layer was washed with water $(3 \times 15 \mathrm{~mL})$ and $\mathrm{NaOH} 10 \%$ aqueous solution $(1 \times 15 \mathrm{~mL})$. After drying the organic layer over anhydrous $\mathrm{MgSO}_{4}$, the solvent was removed under vacuum. The crude solid was purified by column chromatography, eluting with dichloromethane-methanol (100:1). N-(tert-Butyloxycarbonyl)-4-(5'-formylthiophen-2'yl)-L-phenylalanine methyl ester $\mathbf{1 b}$ was obtained as a white solid $(0.101 \mathrm{~g}, 55 \%)$; ${ }^{1} \mathrm{H}$ NMR $(400 \mathrm{MHz}$, $\left.\mathrm{CDCl}_{3}\right): \delta=1.41\left(\mathrm{~s}, 9 \mathrm{H}, \mathrm{C}\left(\mathrm{CH}_{3}\right)_{3}\right), 3.08-3.19\left(\mathrm{~m}, 1 \mathrm{H}, \beta-\mathrm{CH}_{2}\right), 3.73\left(\mathrm{~s}, 3 \mathrm{H}, \mathrm{OCH}_{3}\right), 4.56-4.61(\mathrm{~m}, 1 \mathrm{H}$, $\alpha-\mathrm{H}), 5.07$ (d, J 7.2 Hz, 1H, NH Boc), 7.19 (d, J 8.2 Hz, 2H, H2 and H6), 7.37 (d, J 4.0 Hz, 1H, H3'), 7.59 (d, J 8.2 Hz, 2H, H3 and H5), 7.72 (d, J 4.0 Hz, 1H, H4), 9.87 (br s, 1H, CHO) ppm; ${ }^{13} \mathrm{C}$ NMR (100.6 MHz, $\left.\mathrm{CDCl}_{3}\right): \delta=28.21\left(\mathrm{C}\left(\mathrm{CH}_{3}\right)_{3}\right), 38.12\left(\beta-\mathrm{CH}_{2}\right), 52.28\left(\mathrm{OCH}_{3}\right), 54.25(\alpha-\mathrm{C}), 79.92$ 
$\left(C\left(\mathrm{CH}_{3}\right)_{3}\right), 123.92\left(\mathrm{C}^{\prime}\right), 126.41(\mathrm{C} 3$ and $\mathrm{C} 5), 130.17(\mathrm{C} 2$ and $\mathrm{C} 6), 131.70(\mathrm{C} 4), 137.38(\mathrm{C} 1), 141.25$ (C4`), 142.27 (C5'), 153.90 (C2), 154.97 (C=O Boc), 171.54 (C=O ester), 182.70 (CHO) ppm.

\subsection{Synthesis of $4^{\prime}$-amino-5' ${ }^{\prime}$-nitrobenzo-18-crown-6, $2 \mathrm{~b}$}

4'-Nitrobenzo-18-crown-6 (0.107 g, $\left.0.3 \times 10^{-3} \mathrm{~mol}\right)$ was dissolved in methanol/acetic acid (10:1) (5 $\mathrm{mL}), \mathrm{Pd} / \mathrm{C}(10 \mathrm{mg})$ was added and the mixture was stirred in $\mathrm{H}_{2}$ atmosphere at room temperature for 20 hours. The solvent was removed in a rotary evaporator and 4'-aminobenzo-18-crown-6 was obtained as a yellow oil (0.096 g, 98\%); ${ }^{1} \mathrm{H}$ NMR (400 MHz, $\left.\mathrm{CDCl}_{3}\right): \delta=3.60-3.66(\mathrm{~m}, 12 \mathrm{H}, 6 \times$ $\mathrm{CH}_{2}$ ), 3.81-3.82 (m, 4H, $\left.2 \times \mathrm{CH}_{2}\right), 4.02-4.03\left(\mathrm{~m}, 4 \mathrm{H}, 2 \times \mathrm{CH}_{2}\right), 6.33-6.37$ (m, 2H, H3' and H6'), 6.65$6.67\left(\mathrm{~m}, 3 \mathrm{H}, \mathrm{H}^{\prime}\right.$ and $\left.\mathrm{NH}_{2}\right) \mathrm{ppm}$.

$4^{\prime}$-Aminobenzo-18-crown-6 (0.078 g, $0.24 \times 10^{-3} \mathrm{~mol}, 1$ equiv) was suspended in acetic anhydride (5 $\mathrm{mL})$ and $\mathrm{Cu}\left(\mathrm{NO}_{3}\right)_{2} .3 \mathrm{H}_{2} \mathrm{O}\left(0.058 \mathrm{~g}, 0.24 \times 10^{-3} \mathrm{~mol}, 1\right.$ equiv $)$ was added. The mixture was stirred at room temperature during 1 hour. The mixture was diluted with $\mathrm{CHCl}_{3}(10 \mathrm{~mL})$ and saturated $\mathrm{Na}_{2} \mathrm{CO}_{3}$ solution $(10 \mathrm{~mL})$ was added. After complete acetic anhydride hydrolysis, the organic layer was dried over anhydrous $\mathrm{MgSO}_{4}$ and the solvent was removed under vacuum. The crude was submitted to silica gel column chromatography using mixtures of dichloromethane and methanol of increasing polarity as eluent. The fractions containing the purified product were collected and evaporated under vacuum, to yield $N$-(4'-(5'-nitrobenzo-18-crown-6))nitrous amide as a yellow oil $(0.081 \mathrm{~g}, 91 \%) ;{ }^{1} \mathrm{H}$ NMR $(400$ $\left.\mathrm{MHz} \mathrm{CDCl}_{3}\right): \delta=3.67-3.98\left(\mathrm{~m}, 16 \mathrm{H}, 8 \times \mathrm{CH}_{2}\right), 4.22-4.31\left(\mathrm{~m}, 4 \mathrm{H}, 2 \times \mathrm{CH}_{2}\right), 7.70\left(\mathrm{~s}, 1 \mathrm{H}, \mathrm{H} 3^{\prime}\right), 8.47$ (s, 1H, H6’ $\mathrm{ppm}^{\prime}$

The previous compound $\left(0.050 \mathrm{~g}, 0.13 \times 10^{-3} \mathrm{~mol}\right)$ was treated with concentrated $\mathrm{HCl}(2 \mathrm{~mL})$ in 1,2 dicloroethane $(10 \mathrm{~mL})$ and diethyl ketone $\left(0.4 \mathrm{~mL}, 3.9 \times 10^{-3} \mathrm{~mol}, 30\right.$ equiv) by stirring under pressure at $80{ }^{\circ} \mathrm{C}$ for 4 hours. The mixture was neutralized with triethylamine. The solvent was removed under vacuum and the residue purified by silica gel column chromatography using mixtures of dichloromethane and methanol of increasing polarity as eluent. $4^{\prime}$-Amino-5' -nitrobenzo-18-crown-6 2b was obtained as a yellow oil (0.041 g, 48\%); ${ }^{1} \mathrm{H}$ NMR $\left(400 \mathrm{MHz}, \mathrm{CDCl}_{3}\right): \delta=3.60-3.75(\mathrm{~m}, 12 \mathrm{H}$, $\left.6 \times \mathrm{CH}_{2}\right), 3.85-3.87\left(\mathrm{~m}, 4 \mathrm{H}, 2 \times \mathrm{CH}_{2}\right), 4.06-4.22\left(\mathrm{~m}, 4 \mathrm{H}, 2 \times \mathrm{CH}_{2}\right), 6.24\left(\mathrm{~s}, 1 \mathrm{H}, \mathrm{H} 3^{\prime}\right), 7.42(\mathrm{~s}, 1 \mathrm{H}$, H6’) $\mathrm{ppm}$.

\subsection{Synthesis of 15-crown-5-benzimidazolyl phenylalanine, 3}

A solution of $N$-(tert-butyloxycarbonyl)-4-formyl-L-phenylalanine methyl ester 1a [8] (0.34 g, $0.11 \times$ $10^{-3} \mathrm{~mol}, 1$ equiv) and $4^{\prime}$-amino-5'-nitrobenzo-15-crown-5 2a (0.035 g, $0.11 \times 10^{-3} \mathrm{~mol}, 1$ equiv $)$ in absolute ethanol $(3 \mathrm{~mL})$ was treated with $\mathrm{Na}_{2} \mathrm{~S}_{2} \mathrm{O}_{4}\left(0.057 \mathrm{~g}, 0.33 \times 10^{-3} \mathrm{~mol}, 3\right.$ equiv $)$, dissolved in 
water $(1 \mathrm{~mL})$, and heated at $80^{\circ} \mathrm{C}$ with stirring for $15 \mathrm{~h}$. The mixture was poured into water $(20 \mathrm{~mL})$ and extracted with ethyl acetate $(3 \times 20 \mathrm{~mL})$. The organic layer was dried with anhydrous $\mathrm{MgSO}_{4}$ and evaporated under reduced pressure to give the crude product that was submitted to silica gel column chromatography using mixtures of dichloromethane and $n$-hexane of increasing polarity as eluent. The fractions containing the purified product were collected and evaporated under vacuum, giving crown ether benzimidazolyl phenylalanine methyl ester 3 as a yellow oil $(0.044 \mathrm{~g}, 70 \%) ;{ }^{1} \mathrm{H}$ NMR $(400 \mathrm{MHz}$, $\left.\mathrm{CDCl}_{3}\right): \delta=1.42\left(\mathrm{~s}, 9 \mathrm{H}, \mathrm{C}\left(\mathrm{CH}_{3}\right)_{3}\right), 2.83-2.88\left(\mathrm{~m}, 1 \mathrm{H}, \beta-\mathrm{CH}_{2}\right), 3.06-3.10\left(\mathrm{~m}, 1 \mathrm{H}, \beta-\mathrm{CH}_{2}\right), 3.68-3.98$ $\left(\mathrm{m}, 19 \mathrm{H}, 8 \times \mathrm{CH}_{2}\right.$ and $\left.\mathrm{OCH}_{3}\right), 4.55-4.57(\mathrm{~m}, 1 \mathrm{H}, \alpha-\mathrm{H}), 5.30$ (d, J 7.2 Hz, 1H, NH Boc), 7.04 (s, 1H, $\mathrm{H}^{\prime}{ }^{\prime}$ and H7'), 7.19 (d, J 7.6 Hz, 2H, H2 and H6), 8.15 (d, J 7.2 Hz, 2H, H3 and H5); ${ }^{13} \mathrm{C}$ NMR (100.6 $\left.\mathrm{MHz}, \mathrm{CDCl}_{3}\right): \delta=28.32\left(\mathrm{C}\left(\mathrm{CH}_{3}\right)_{3}\right), 38.08\left(\beta-\mathrm{CH}_{2}\right), 51.74\left(\mathrm{CH}_{2}\right), 52.35\left(\mathrm{OCH}_{3}\right), 54.42(\alpha-\mathrm{C}), 68.03$ $\left.\left(\mathrm{CH}_{2}\right), 68.64\left(\mathrm{CH}_{2}\right), 69.36\left(\mathrm{CH}_{2}\right), 69.94\left(\mathrm{CH}_{2}\right), 70.44\left(\mathrm{CH}_{2}\right), 70.52\left(\mathrm{CH}_{2}\right), 80.09\left(\mathrm{C}_{\left(\mathrm{CH}_{3}\right)}\right)_{3}\right), 98.69$ (C4', C7’), 126.86 (C3, C5), 130.02 (C2, C6), 131.01 (C4), 137.80 (C1), 138.51 (C3a', C7a'), 146.17 (C5', C6'), 155.23 (C2', C=O Boc), 172.08 (C=O ester); UV/Vis (acetonitrile, $\mathrm{nm}$ ): $\lambda_{\max }(\log \varepsilon)=325$ (4.20); MS: $m / z$ (ESI) 586 ([M+H] $\left.]^{+}, 100\right), 586$ (20); HMRS: $m / z$ (ESI) calc. for $\mathrm{C}_{30} \mathrm{H}_{40} \mathrm{~N}_{3} \mathrm{O}_{9} 586.2755$, found 586.2759 .

\subsection{General method for the synthesis of crown ether benzimidazolyl 4-(5'-formylthiophen-2'- yl)-L-phenylalanines 4a-b}

A solution of $\mathrm{N}$-(tert-butyloxycarbonyl)-4-(5'-formylthiophen-2'-yl)-L-phenylalanine methyl ester $\mathbf{1 b}$ $\left(0.050 \mathrm{~g}, 0.13 \times 10^{-3} \mathrm{~mol}, 1\right.$ equiv) and $4^{\prime}$-amino-5'-nitrobenzo-15-crown-5 2a (0.042 $\mathrm{g}, 0.13 \times 10^{-3}$ mol, 1 equiv) or 4'-amino-5'-nitrobenzo-18-crown-6 $2 \mathbf{b}\left(0.048 \mathrm{~g}, 0.13 \times 10^{-3} \mathrm{~mol}, 1\right.$ equiv) in absolute ethanol ( $3 \mathrm{~mL})$ was treated with $\mathrm{Na}_{2} \mathrm{~S}_{2} \mathrm{O}_{4}\left(0.067 \mathrm{~g}, 0.39 \times 10^{-3} \mathrm{~mol}, 3\right.$ equiv $)$, dissolved in water $(1$ $\mathrm{mL}$ ), and heated at $80^{\circ} \mathrm{C}$ with stirring for $48 \mathrm{~h}$. The mixture was evaporated under reduced pressure to give the crude benzimidazolyl phenylalanines $\mathbf{4 a}$ and $\mathbf{4 b}$, respectively. The crudes were submitted to silica gel column chromatography using mixtures of dichloromethane and methanol of increasing polarity as eluent. The fractions containing the purified products were collected and evaporated under vacuum.

2.4.1. 15-Crown-5 benzimidazolyl phenylalanine methyl ester $4 a$ was obtained as a yellow oil (0.034 g, 40\%); ${ }^{1} \mathrm{H}$ NMR (400 MHz, $\left.\mathrm{CDCl}_{3}\right): \delta=1.45$ (s, 9H, $\left.\mathrm{C}\left(\mathrm{CH}_{3}\right)_{3}\right), 3.04-3.17\left(\mathrm{~m}, 1 \mathrm{H}, \beta-\mathrm{CH}_{2}\right)$, 3.73-4.05 (m, 16H, $\left.8 \times \mathrm{CH}_{2}\right), 3.74\left(\mathrm{~s}, 3 \mathrm{H}, \mathrm{OCH}_{3}\right), 4.55-4.60(\mathrm{~m}, 1 \mathrm{H}, \alpha-\mathrm{H}), 5.12(\mathrm{~d}, J 7.6 \mathrm{~Hz}, 1 \mathrm{H}, \mathrm{NH}$ Boc), 7.17-7.22 (m, 2H, H4` and H7`), 7.19 (d, J 7.8 Hz, 2H, H2 and H6), 7.36 (br s, 1H, H3’'), 7.60 $\left(\mathrm{d}, J 7.8 \mathrm{~Hz}, 2 \mathrm{H}, \mathrm{H} 3\right.$ and H5), 8.01 (br s, $\left.1 \mathrm{H}, \mathrm{H} 4{ }^{\prime \prime}\right) ;{ }^{13} \mathrm{C} \mathrm{NMR}\left(100.6 \mathrm{MHz}, \mathrm{CDCl}_{3}\right): \delta=28.31$ $\left(\mathrm{C}\left(\mathrm{CH}_{3}\right)_{3}\right), 38.03\left(\beta-\mathrm{CH}_{2}\right), 52.39\left(\mathrm{OCH}_{3}\right), 54.37(\alpha-\mathrm{C}), 67.69\left(\mathrm{CH}_{2}\right), 68.75\left(\mathrm{CH}_{2}\right), 69.22\left(\mathrm{CH}_{2}\right), 69.39$ 
$\left(\mathrm{CH}_{2}\right), 69.42\left(\mathrm{CH}_{2}\right), 80.03\left(\mathrm{C}_{\left.\left(\mathrm{CH}_{3}\right)_{3}\right),} 97.31\left(\mathrm{C}^{\prime}, \mathrm{C}^{\prime}\right), 124.89\left(\mathrm{C}^{\prime \prime}\right), 126.28(\mathrm{C} 3, \mathrm{C} 5), 130.23(\mathrm{C} 2\right.$, C6), 131.05 (C4), 133.61 (C4'”), 137.73 (C1), 138.59 (C3a', C7a'), 143.72 (C5'), 146.70 (C5', C6’), 147.52 (C5), 151.29 (C2”), 155.10 (C2', C=O Boc), 172.06 (C=O ester); UV/Vis (acetonitrile, nm): $\lambda_{\max }(\log \varepsilon)=370$ (4.15); MS: $m / z(E S I) 668\left([\mathrm{M}+\mathrm{H}]^{+}, 34\right), 682$ (100), 690 (9), 704 (26); HMRS: $\mathrm{m} / z$ (ESI) calc. for $\mathrm{C}_{34} \mathrm{H}_{42} \mathrm{~N}_{3} \mathrm{O}_{9} \mathrm{~S} 668.2640$, found 668.2636 .

2.4.2. 18-Crown-6 benzimidazolyl phenylalanine methyl ester $4 \mathrm{~b}$ was obtained as a yellow oil (0.036 g, 39\%); ${ }^{1} \mathrm{H}$ NMR (400 MHz, $\left.\mathrm{CDCl}_{3}\right): \delta=1.44\left(\mathrm{~s}, 9 \mathrm{H}, \mathrm{C}\left(\mathrm{CH}_{3}\right)_{3}\right), 3.01-3.16\left(\mathrm{~m}, 1 \mathrm{H}, \beta-\mathrm{CH}_{2}\right)$, 3.59-3.86 (m, 20H, $\left.10 \times \mathrm{CH}_{2}\right), 3.74\left(\mathrm{~s}, 3 \mathrm{H}, \mathrm{OCH}_{3}\right), 4.56-4.60(\mathrm{~m}, 1 \mathrm{H}, \alpha-\mathrm{H}), 5.09(\mathrm{~d}, J 8.0 \mathrm{~Hz}, 1 \mathrm{H}, \mathrm{NH}$ Boc), 7.08 (s, 2H, H4' and H7’), 7.12-7.16 (m, 2H, H2 and H6), 7.24 (br s, 1H, H3”`), 7.53 (d, J 7.2 $\mathrm{Hz}, 2 \mathrm{H}, \mathrm{H} 3$ and H5), 7.95 (br s, $\left.1 \mathrm{H}, \mathrm{H} 4{ }^{\prime \prime}\right) ;{ }^{13} \mathrm{C} \mathrm{NMR}\left(100.6 \mathrm{MHz}, \mathrm{CDCl}_{3}\right): \delta=28.29\left(\mathrm{C}\left(\mathrm{CH}_{3}\right)_{3}\right), 38.03$ $\left(\beta-\mathrm{CH}_{2}\right), 52.31\left(\mathrm{OCH}_{3}\right), 54.39(\alpha-\mathrm{C}), 67.13\left(\mathrm{CH}_{2}\right), 68.51\left(\mathrm{CH}_{2}\right), 69.24\left(\mathrm{CH}_{2}\right), 69.30\left(\mathrm{CH}_{2}\right), 69,45$

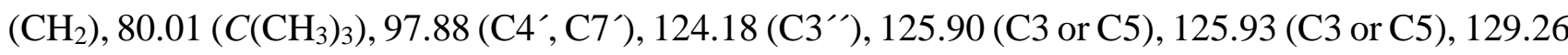
(C4”), 129.92 (C2 or C6), 129.99 (C2 or C6), 132.37 (C4), 136.19 (C1), 138.49 (C3a', C7a'), 143.92 (C5”), 145.33 (C5' and C6’), 151.28 (C2”), 155.09 (C2, C=O Boc), 172.18 (C=O ester); UV/Vis (acetonitrile, $\mathrm{nm}): \lambda_{\max }(\log \varepsilon)=368$ (4.16); MS: $m / z$ (ESI) $712\left([\mathrm{M}+\mathrm{H}]^{+}, 82\right), 726(100), 734$ (58), 748 (63); HMRS: $m / z$ (ESI) calc. for $\mathrm{C}_{30} \mathrm{H}_{40} \mathrm{~N}_{3} \mathrm{O}_{9} 712.2901$, found 712.2898.

\subsection{Spectrofluorimetric titrations and chemosensing studies of benzimidazolyl phenylalanines 3 and 4}

Solutions of phenylalanine 3 and $\mathbf{4}\left(\mathrm{ca} .1 .0 \times 10^{-5} \mathrm{M}\right)$ and of the cations under study $\left(\mathrm{ca} .1 .0 \times 10^{-2} \mathrm{M}\right)$ were prepared in UV-grade acetonitrile and mixtures of acetonitrile and water, in different ratios (in the form of hydrated tetrafluorborate salts for $\mathrm{Cu}^{2+}, \mathrm{Co}^{2+}, \mathrm{Ni}^{2+}$ and $\mathrm{Pd}^{2+}$, and perchlorate salts for $\mathrm{Cd}^{2+}$, $\mathrm{Ca}^{2+}, \mathrm{Na}^{+}, \mathrm{Cr}^{3+}, \mathrm{Zn}^{2+}, \mathrm{Hg}^{2+}, \mathrm{Fe}^{2+}$ and $\left.\mathrm{Fe}^{3+}\right)$. Titration of the compounds with the several metallic cations was performed by the sequential addition of equivalents of metal cation to the phenylalanine derivative solution, in a $10 \mathrm{~mm}$ path length quartz cuvette and emission spectra were measured by excitation at the wavelength of maximum absorption for compounds $\mathbf{3}$ and $\mathbf{4}$. The binding stoichiometry of the phenylalanine derivatives $\mathbf{3}$ and $\mathbf{4}$ with the metal cations was determined by Hyperquad software.

\section{Results and discussion}

\subsection{Synthesis}

The precursors $\mathbf{1}$ and $\mathbf{2}$ (Figure 1) were used in the synthesis of the crown ether-amino acid derivatives $\mathbf{3}$ and $\mathbf{4 a - b .}$ 


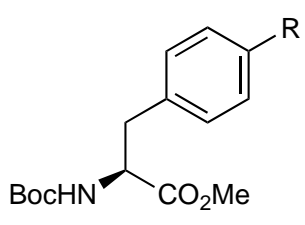

1 a $\mathrm{R}=\mathrm{CHO}$

b $\mathrm{R}=\sqrt{\mathrm{S}} \mathrm{CHO}_{\mathrm{CHO}}$

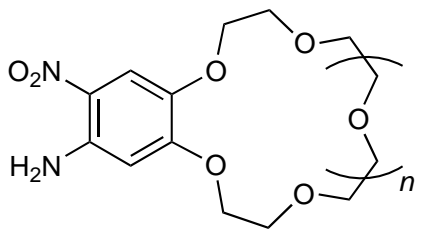

2 a $n=1$

b $\mathrm{n}=2$

Figure 1. Structure of used precursors 1 and 2.

$N$-(tert-Butyloxycarbonyl)-4-formyl-L-phenylalanine methyl ester 1a was synthesised according to a previously published procedure [8] and 4'-amino-5'-nitrobenzo-15-crown-5 2a was commercially available. $N$-tert-Butyloxycarbonyl-4-(5'-formylthiophen-2'-yl)-L-phenylalanine methyl ester $\mathbf{1 b}$ was obtained by a Suzuki coupling from $N$-(tert-butyloxycarbonyl)-4-bromo-L-phenylalanine methyl ester and 2-formyl-5-thiophene boronic acid in moderate yield (57\%) (Scheme 1). The precursor 4bromophenylalanine was commercially available and was protected at its $\mathrm{N}$ - and $\mathrm{C}$ - terminals by the usual protection methods. The new 4'-amino-5'-nitrobenzo-18-crown-6 $\mathbf{2 b}$ was synthesised from 4'nitrobenzo-18-crown-6 by reduction of the nitro group (98\% yield) and subsequent nitration and denitrosation (91 and $48 \%$ yield, respectively) (Scheme 2 ).
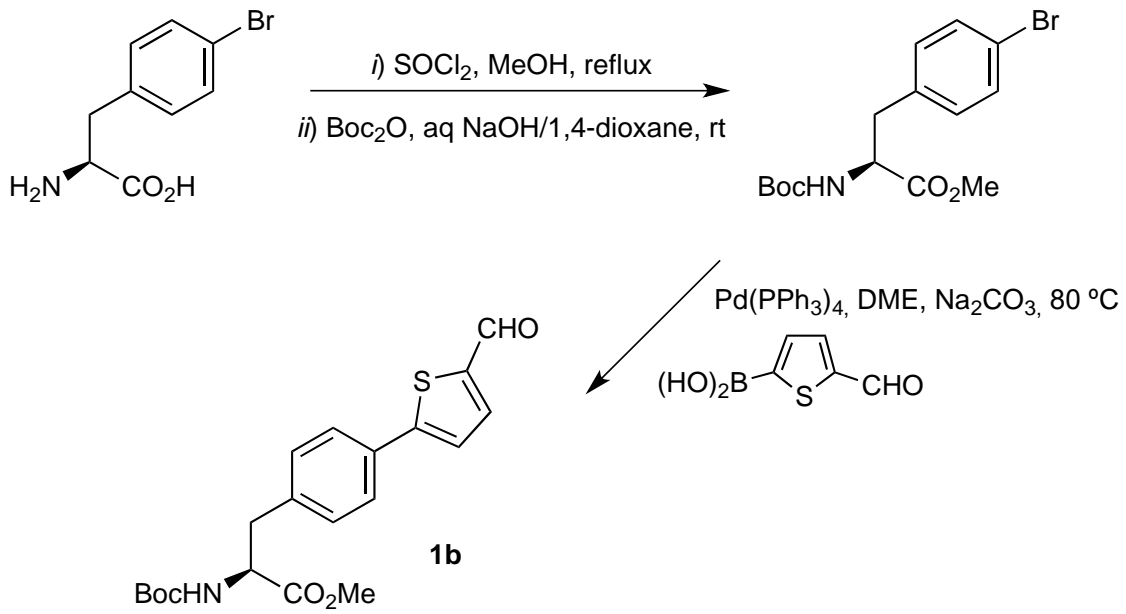

Scheme 1. Synthesis of phenylalanine derivative $\mathbf{1 b}$. 
<smiles>O=[N+]([O-])c1ccc2c(c1)OCCOCCOCCOCCOCCO2</smiles>

$\underset{\mathrm{Pd} / \mathrm{C}, \mathrm{H}_{2}, \mathrm{rt}}{\mathrm{MeOH} / \mathrm{AcOH}(10: 1)}$

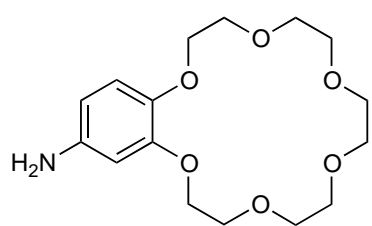

acetic anhydride $\mathrm{Cu}\left(\mathrm{NO}_{3}\right)_{2} \cdot 3 \mathrm{H}_{2} \mathrm{O}$<smiles>Nc1cc2c(cc1[N+](=O)[O-])OCCOCCOCCOCCOCCO2</smiles>

conc. $\mathrm{HCl}$,
1,2-dichloroethan

$\leftarrow 80^{\circ} \mathrm{C}$

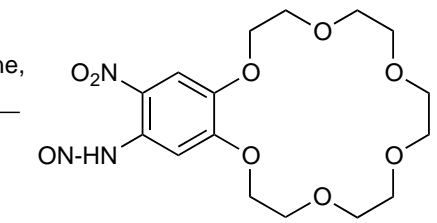

Scheme 2. Synthesis of crown ether derivative $\mathbf{2 b}$.

Compound 3 was synthesized in 70\% yield by condensation of $N$-(tert-butyloxycarbonyl)-4-formyl-Lphenylalanine methyl ester 1a with 4'-amino-5'-nitrobenzo-15-crown-5-ether 2a in the presence of $\mathrm{Na}_{2} \mathrm{~S}_{2} \mathrm{O}_{4}$ in ethanol at $80{ }^{\circ} \mathrm{C}$, (Scheme 3). Compounds $4 \mathbf{a}$ and $\mathbf{4 b}$ were synthesized from $N$-(tertbutyloxycarbonyl)-4-(5'-formylthiophen-2'-yl)-L-phenylalanine methyl ester $\mathbf{1 b}$ and crown ethers $\mathbf{2 a}$ and $\mathbf{2 b}$, using the same procedure described above, in 40 and $39 \%$ yield, respectively. To the best of our knowledge, this is the first time that this synthetic methodology is applied in order to prepare imidazo-benzocrown ether derivatives using as precursors an amino acid, $4^{\prime}$-amino-5' ${ }^{\prime}$-nitrobenzo-15crown-5' and 4'-amino-5'-nitrobenzo-18-crown-6. The synthesized compounds were fully characterized by the usual spectroscopic techniques.

\subsection{Photophysical studies of compounds 3 and 4}

The photophysical properties of compounds $\mathbf{3}$ and $\mathbf{4}$ in acetonitrile were evaluated and the UV/Vis absorption and emission spectra of degassed $10^{-5} \mathrm{M}$ solutions were measured. Relative fluorescence quantum yields were calculated using 9,10-diphenylanthracene in ethanol as standard $\left(\Phi_{\mathrm{F}}=0.95\right)$ [7]. Compounds 3 and 4 exhibited maximum absorption between 325 and $370 \mathrm{~nm}$ and emission between 392 and $456 \mathrm{~nm}$. Considering the structure of the compounds, it could be seen that the introduction of the thiophene spacer in $\mathbf{4 a}$ and $\mathbf{4 b}$ induced a bathochromic shift in the absorption band of 45 and 43 nm, respectively, compared to $\mathbf{3}$ (Table 1, Figure 2 for $\mathbf{3}$ and $\mathbf{4 a}$ as representative example). This trend was also observed for the emission spectra. The relative fluorescence quantum yields and Stokes' shifts for $\mathbf{4 a}$ and $\mathbf{4 b}$ were also higher than those of $\mathbf{3}$, confirming the modulation of the photophysical properties caused by the presence of the thiophene [6d,9]. 


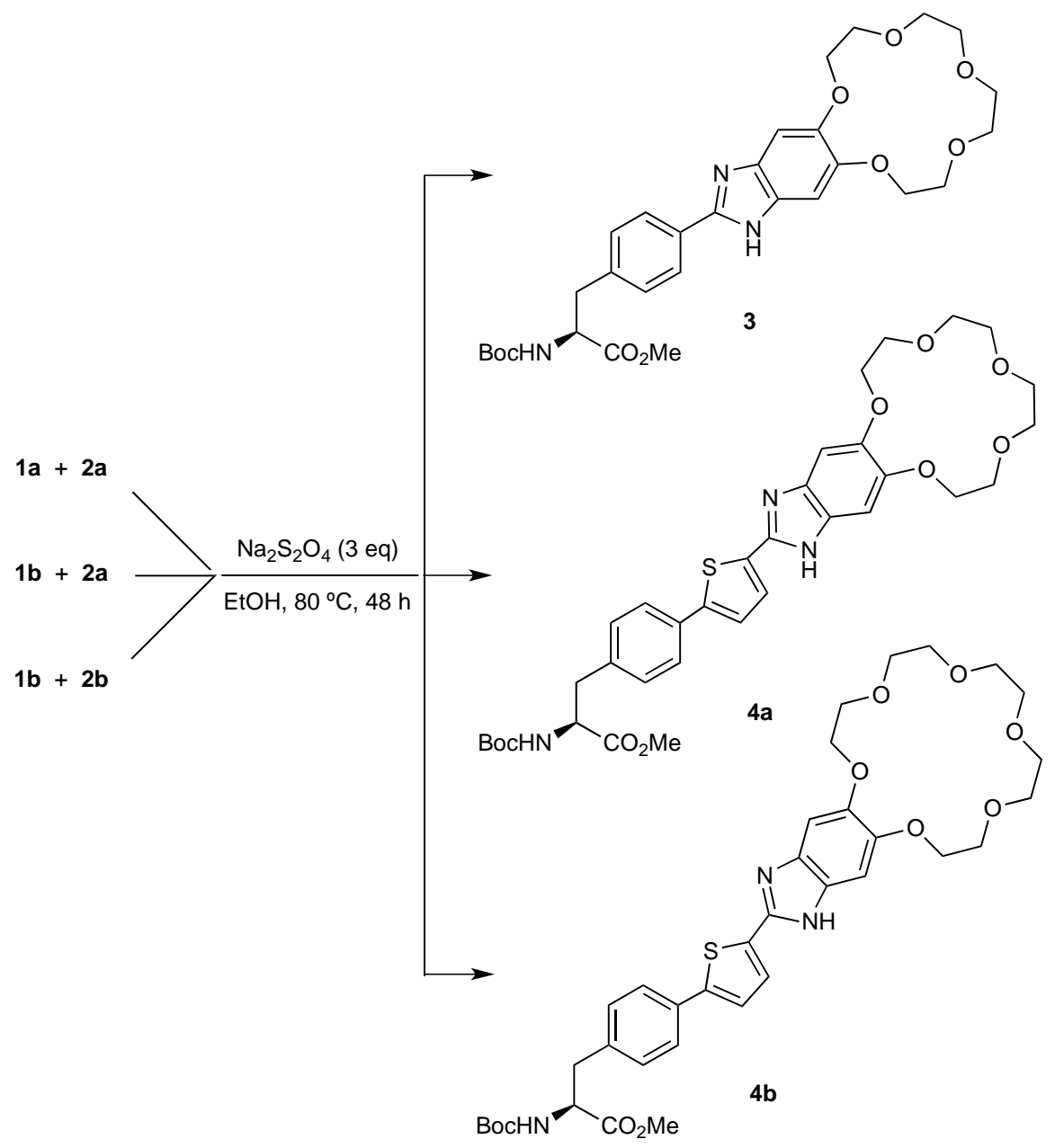

Scheme 3. Synthesis of crown ether-amino acid derivatives 3 and 4.

Table 1. Yields, UV-visible absorption and fluorescence data for crown ether benzimidazolyl phenylalanines 3-4 in acetonitrile.

\section{$\mathrm{UV} / \mathrm{Vis}$}

Fluorescence

Cpd. Yield

$(\%)$

$\lambda_{\max } \quad \log \varepsilon \quad \lambda_{\text {em }}$

Stokes'shift

$(\mathrm{nm}) \quad\left(\mathrm{cm}^{-1}\right)$

\begin{tabular}{cccccccc}
\hline $\mathbf{3}$ & 70 & 325 & 4.20 & 392 & 67 & 5259 & 0.59 \\
$\mathbf{4 a}$ & 40 & 370 & 4.15 & 456 & 86 & 5097 & 0.95 \\
$\mathbf{4 b}$ & 39 & 368 & 4.16 & 456 & 88 & 5244 & 0.94 \\
\hline
\end{tabular}




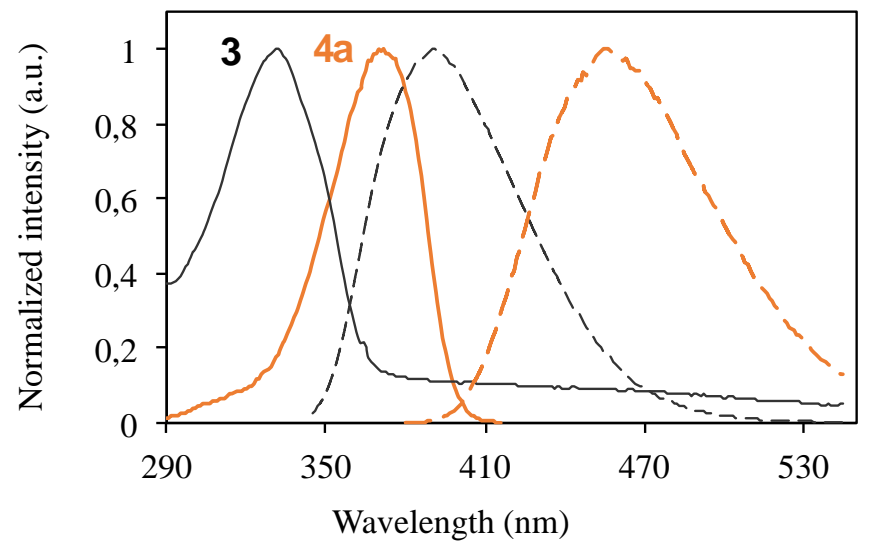

Figure 2. Normalized UV-visible absorption (solid line) and emission spectra (broken line) for compounds $\mathbf{3}$ and $\mathbf{4 a}$ in acetonitrile $\left(\mathbf{3}, \lambda_{\mathrm{exc}}=325 \mathrm{~nm} ; \mathbf{4 a}, \lambda_{\mathrm{exc}}=370 \mathrm{~nm}, \mathrm{~T}=298 \mathrm{~K}\right)$.

Due to the donor-acceptor character of the synthesised imidazo-benzimidazole crown ethers, it was decided to study the absorption and emission solvatochromic behaviour of derivatives $\mathbf{4}$ in the presence of protic and aprotic solvents with different polarities such as diethyl ether, 1,4-dioxane, ethanol, acetonitrile, dichloromethane and dimethylsulfoxide (Table 2). Both compounds exhibited positive solvatochromism with respect to their charge transfer (CT) absorption band $\left(\Delta v=4444-5161 \mathrm{~cm}^{-1}\right)$. Therefore, compounds $\mathbf{4}$ appear to be have potential application as solvent polarity probes.

Table 2. Solvatochromic data $\left(\lambda_{\max }\right.$ and $\lambda_{\mathrm{em}}$, in $\mathrm{nm}$, and relative fluorescent quantum yields, $\Phi_{\mathrm{F}}$ ) for benzimidazolyl phenylalanines derivatives $\mathbf{4 a - b}$ with $\pi^{*}$ values by Kamlet and Taft [10].

\begin{tabular}{|c|c|c|c|c|c|c|c|}
\hline & $\pi^{*}$ & $\begin{array}{c}\text { Diethyl ether } \\
(0.27)\end{array}$ & $\begin{array}{c}\text { Dioxane } \\
(0.55)\end{array}$ & $\begin{array}{l}\mathrm{EtOH} \\
(0.54)\end{array}$ & $\begin{array}{l}\mathrm{ACN} \\
(0.75)\end{array}$ & $\begin{array}{l}\text { DCM } \\
(0.82)\end{array}$ & $\begin{array}{r}\text { DMSO } \\
(1.00)\end{array}$ \\
\hline \multirow{4}{*}{$4 a$} & $\lambda_{\max }(\mathrm{nm})$ & 363 & 368 & 375 & 370 & 371 & 379 \\
\hline & $\lambda_{\mathrm{em}}(\mathrm{nm})$ & 435 & 450 & 450 & 456 & 449 & 470 \\
\hline & $\Delta v\left(\mathrm{~cm}^{-1}\right)$ & 4560 & 4952 & 4444 & 5097 & 4682 & 5109 \\
\hline & $\Phi_{\mathrm{F}}$ & 0.93 & 0.90 & 0.91 & 0.95 & 0.91 & 0.90 \\
\hline \multirow{4}{*}{$4 b$} & $\lambda_{\max }(\mathrm{nm})$ & 363 & 369 & 372 & 368 & 368 & 375 \\
\hline & $\lambda_{\mathrm{em}}(\mathrm{nm})$ & 439 & 447 & 451 & 456 & 449 & 465 \\
\hline & $\Delta v\left(\mathrm{~cm}^{-1}\right)$ & 4769 & 4729 & 4709 & 5244 & 4902 & 5161 \\
\hline & $\Phi_{\mathrm{F}}$ & 0.93 & 0.90 & 0.94 & 0.94 & 0.92 & 0.91 \\
\hline
\end{tabular}




\subsection{Spectrofluorimetric titrations of compounds 3 and 4 with metallic cations}

The modification of phenylalanine through the introduction of UV-active and highly fluorescent heterocycles (benzimidazole, thiophene) and crown ether moieties was expected to provide additional binding sites for a variety of metal ions through the heterocycle donor atoms, as well as improved photophysical properties for the chemosensing studies of compounds $\mathbf{3}$ and $\mathbf{4 a - b}$. With these heterocyclic phenylalanine derivatives it was intended to assess the influence of the different $\pi$-bridges and of the size of the crown ether at the benzimidazole system in the chemosensing ability of metallic cations.

Considering the biological, environmental and analytical relevance of transition metals such as $\mathrm{Ca}^{2+}$, $\mathrm{Cd}^{2+}, \mathrm{Co}^{2+}, \mathrm{Cr}^{3+}, \mathrm{Cu}^{2+}, \mathrm{Fe}^{2+}, \mathrm{Fe}^{3+}, \mathrm{Hg}^{2+}, \mathrm{Na}^{+}, \mathrm{Ni}^{2+}, \mathrm{Pd}^{2+}$ and $\mathrm{Zn}^{2+}$, the interaction of compounds 3-4 with these cations was evaluated through UV-vis and fluorescence spectroscopy in spectrophotometric and spectrofluorimetric titrations in acetonitrile. A preliminary evaluation of the chemosensing ability was performed by addition of 100 equiv of each cation to $1.0 \times 10^{-5} \mathrm{M}$ acetonitrile solutions of $\mathbf{3}$ and 4a-b and the changes in the UV-vis absorption and fluorescence spectra were recorded. In the UV-vis absorption spectra, no changes were seen in the bands corresponding to the maximum wavelength of absorption of phenylalanine derivatives 3-4 after addition of up to 100 equiv of each metal cation, but noticeable changes occurred in the emission spectra and in the relative fluorescence quantum yield (Table 3, Figure 3 and Figures S2-S11 in supporting information, for 3 as representative example).

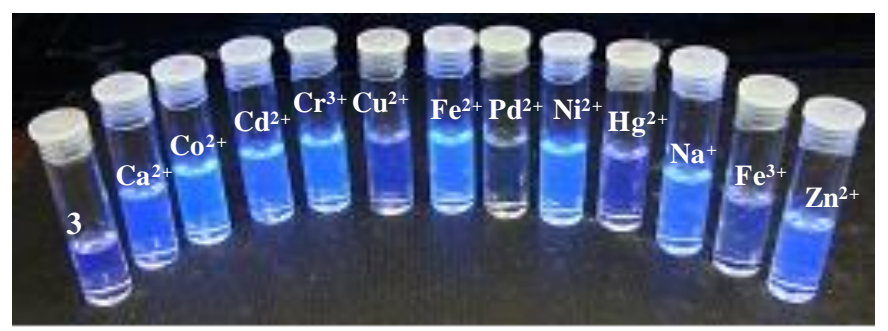

Figure 3. Fluorescence of solutions of phenylalanine $3\left(1.0 \times 10^{-5} \mathrm{M}\right)$ in acetonitrile in the presence of 100 equivalents of several cations, visualised under a $365 \mathrm{~nm}$ lamp. 
Table 3. Wavelengths of maximum fluorescence $\left(\lambda_{\mathrm{em}}\right)$ and relative fluorescent quantum yields $\left(\Phi_{\mathrm{F}}\right)$ for benzimidazolyl phenylalanines 3-4, in acetonitrile, in the presence of 100 equivalents of several cations $\left([\mathbf{3}]=[\mathbf{4}]=1.0 \times 10^{-5} \mathrm{M}\right)$.

\begin{tabular}{|c|c|c|c|c|c|c|}
\hline \multirow[b]{2}{*}{ Cation } & \multicolumn{2}{|c|}{3} & \multicolumn{2}{|c|}{$4 \mathbf{a}$} & \multicolumn{2}{|c|}{$4 b$} \\
\hline & $\lambda_{\mathrm{em}}(\mathbf{n m})$ & $\Phi_{\mathrm{F}}$ & $\lambda_{\mathrm{em}}(\mathrm{nm})$ & $\Phi_{\mathrm{F}}$ & $\lambda_{\mathrm{em}}(\mathbf{n m})$ & $\Phi_{\mathrm{F}}$ \\
\hline $\mathrm{Ca}^{2+}$ & 366 & 0.44 & 433 & 0.98 & 438 & 0.98 \\
\hline $\mathrm{Co}^{2+}$ & 430 & 0.55 & 472 & 0.61 & 472 & 0.15 \\
\hline $\mathrm{Cd}^{2+}$ & 422 & 0.38 & 473 & 0.64 & 460 & 0.45 \\
\hline $\mathrm{Cr}^{3+}$ & 428 & 0.55 & 460 & 0.59 & 461 & 0.66 \\
\hline $\mathrm{Cu}^{2+}$ & 433 & 0.01 & 433 & 0.001 & 456 & 0.004 \\
\hline $\mathrm{Fe}^{2+}$ & 435 & 0.57 & 480 & 0.86 & 473 & 0.99 \\
\hline $\mathrm{Pd}^{2+}$ & 432 & 0.02 & 474 & 0.001 & 444 & 0.003 \\
\hline $\mathrm{Ni}^{2+}$ & 430 & 0.57 & 476 & 0.73 & 463 & 0.99 \\
\hline $\mathrm{Hg}^{2+}$ & 435 & 0.16 & 474 & 0.90 & 469 & 0.001 \\
\hline $\mathrm{Na}^{+}$ & 382 & 0.44 & 441 & 0.99 & 449 & 0.91 \\
\hline $\mathrm{Fe}^{3+}$ & 428 & 0.42 & 421 & 0.01 & 457 & 0.001 \\
\hline $\mathrm{Zn}^{2+}$ & 366 & 0.44 & 446 & 0.76 & 441 & 0.96 \\
\hline
\end{tabular}

Therefore, spectrofluorimetric titrations of acetonitrile solutions of 3-4 were performed to understand where and how the interaction with the different metal ions was occurring. The stronger interaction for compound 3 was observed in the presence of $\mathrm{Pd}^{2+}$ and $\mathrm{Cu}^{2+}$ with only 1.6 and 3.0 equivalents being enough to quench the emission, as a CHEQ (chelation enhancement of the quenching) effect in the 
fluorescence emission for both metals was observed (Figure 4, for $\mathbf{3}$ as representative example). Interaction with $\mathrm{Pd}^{2+}$ quenched almost $80 \%$ of the initial fluorescence, while for $\mathrm{Cu}^{2+}$ a complete quenching of the fluorescence was achieved, accompanied by a red shift of the emission band in both cases. The quenching effect observed could be attributed to an energy transfer quenching of the $\pi^{*}$ emissive state through low-lying metal-centred unfilled $d$-orbitals for $\mathrm{Pd}^{2+}$ and $\mathrm{Cu}^{2+}$, and to an intersystem crossing mechanism due to the heavy atom effect [4d,e,9].
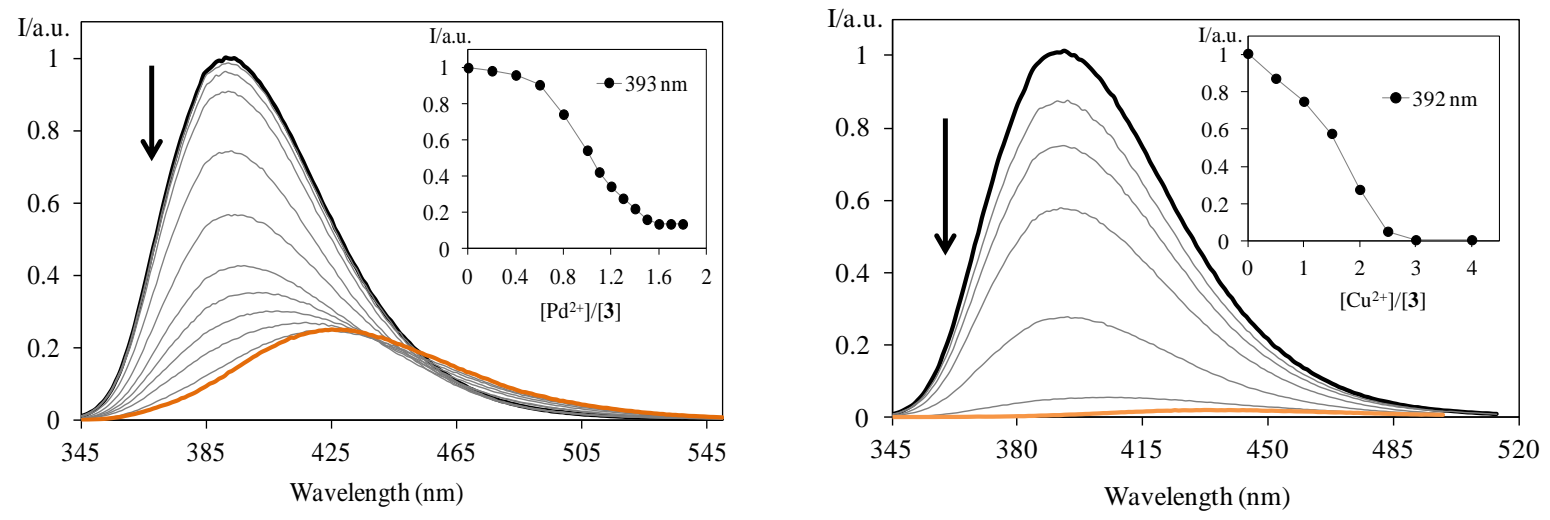

Figure 4. Spectrofluorimetric titrations of compound 3 in the presence of $\left[\mathrm{Pd}\left(\mathrm{CH}_{3} \mathrm{CN}\right)_{4}\left(\mathrm{BF}_{4}\right)_{2}\right]($ left $)$ and $\left[\mathrm{Cu}\left(\mathrm{ClO}_{4}\right)_{2} \cdot 6 \mathrm{H}_{2} \mathrm{O}\right]$ (right), in acetonitrile solution. $\left([3]=1.0 \times 10^{-5} \mathrm{M}, \mathrm{T}=298 \mathrm{~K}, \lambda_{\mathrm{exc}}=325 \mathrm{~nm}\right)$. Inset: normalised emission as a function of added metal equivalents.

A similar quenching behaviour was observed for phenylalanines bearing a thiophene spacer $\mathbf{4 a}$ and $\mathbf{4 b}$ (Figure 5, for $\mathbf{4 a}$ as representative example), although it required a larger amount of cation to ensure complete quenching of the fluorescence (between 40 and 120 equiv), when compared to phenylalanine 3. The stronger interaction for compound $4 \mathbf{a}$ was observed in the presence of $\mathrm{Fe}^{3+}, \mathrm{Pb}^{2+}$ and $\mathrm{Pd}^{2+}$, with a complete quenching of the fluorescence, and interaction with $\mathrm{Cu}^{2+}$ quenched almost $70 \%$ of the initial fluorescence. In the case of compound $\mathbf{4 b}$, it displayed similar chemosensory ability with a complete quenching of the emission upon interaction with $\mathrm{Cu}^{2+}, \mathrm{Fe}^{3+}, \mathrm{Hg}^{2+}$ and $\mathrm{Pd}^{2+}$, but with decreased selectivity as several other cations resulted in 80-90\% fluorescence quenching $\left(\mathrm{Co}^{2+}, \mathrm{Cd}^{2+}, \mathrm{Pb}^{2+}, \mathrm{Cr}^{3+}\right.$ and $\left.\mathrm{Fe}^{2+}\right)$. 

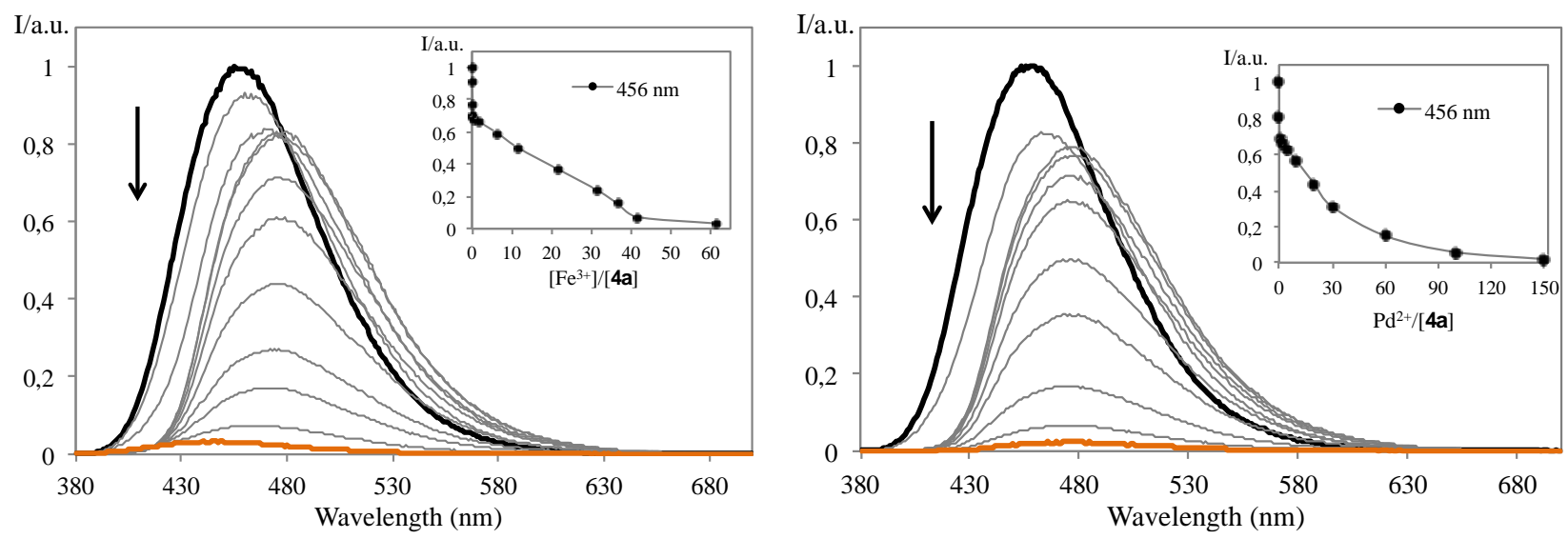

Figure 5. Spectrofluorimetric titrations of compound $4 \mathbf{a}$ in the presence of $\left[\mathrm{Fe}\left(\mathrm{ClO}_{4}\right)_{3} \cdot 6 \mathrm{H}_{2} \mathrm{O}\right](\mathrm{left})$ and $\left[\mathrm{Pd}\left(\mathrm{CH}_{3} \mathrm{CN}\right)_{4}\left(\mathrm{BF}_{4}\right)_{2}\right]$ (right), in acetonitrile solution. $\left([\mathbf{4 a}]=1.0 \times 10^{-5} \mathrm{M}, \mathrm{T}=298 \mathrm{~K}, \lambda_{\mathrm{exc}}=370\right.$ $\mathrm{nm})$. Inset: normalised emission at $456 \mathrm{~nm}$ as a function of added metal equivalents.

In the case of the other metal cations, a 20-60\% quenching was also observed with the growth of a new red-shifted band upon metal addition (for compound 3, between 422 and $435 \mathrm{~nm}$ for $\mathrm{Cr}^{3+}, \mathrm{Cd}^{2+}$, $\mathrm{Co}^{2+}, \mathrm{Hg}^{2+}, \mathrm{Ni}^{2+}$ and $\mathrm{Fe}^{2+}$ ), whereas a blue shift of the original emission band was observed for the remaining cations (for compounds 3 and $\mathbf{4}$, for $\mathrm{Na}^{+}, \mathrm{Ca}^{2+}$, and $\mathrm{Zn}^{2+}$ ) (see Table 3). The presence of $\mathrm{Ca}^{2+}, \mathrm{Na}^{+}$, and $\mathrm{Zn}^{2+}$ induced a blue shift of the emission band suggesting interaction with the crown ether moiety, with the coordination of cations reducing the donor character of the crown ether and producing a hypsochromic shift through a modulation of the HOMO and LUMO energy. On the other hand, the red shifted band in the presence of the other metals should be related to coordination at the imidazo NH group.

It is well known that the benzo-15-crown-5-ether chelating unit is used specifically for $\mathrm{Na}^{+}$sensing. However, the minor spectral changes induced by interaction with $\mathrm{Na}^{+}$suggest that the delocalized charge present in this system could additionally modulate the interaction with the crown ether resulting in small changes in the ground and the excited state, as well as the counter ion $[4 b, 9,11]$.

Additional proof of the different coordination sites was obtained by performing a spectrofluorimetric titration of $\mathrm{Cu}^{2+}$ with prior addition of 5 equivalents of $\mathrm{Ca}^{2+}$. In this experiment, the two effects were combined: chelation of $\mathrm{Ca}^{2+}$ induced a $30 \mathrm{~nm}$ blue shit of the emission band and subsequent chelation of $\mathrm{Cu}^{2+}$ quenched the shifted band. This result confirms that compound $\mathbf{3}$ can is capable of simultaneous detection of two different metal ion analytes (Figure 6). 


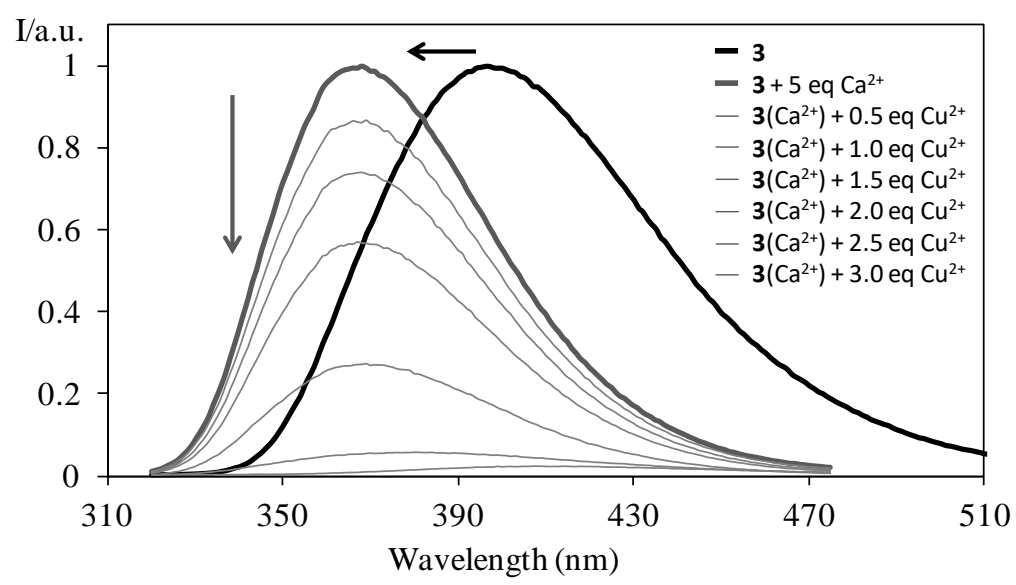

Figure 6. Spectrofluorimetric titration of compound 3 in the presence of 5 equivalents of $\mathrm{Ca}^{2+}$ and subsequent addition of increasing amounts of $\mathrm{Cu}^{2+}$, in acetonitrile solution $\left([3]=1.0 \times 10^{-5} \mathrm{M}, \mathrm{T}=\right.$ $\left.298 \mathrm{~K}, \lambda_{\mathrm{exc}}=325 \mathrm{~nm}\right)$.

Having in mind practical applications of compounds $\mathbf{3}$ and $\mathbf{4}$ in aqueous media the chemosensory ability was also evaluated in mixtures of acetonitrile and water in varying proportions. The best results were obtained in acetonitrile/ $\mathrm{H}_{2} \mathrm{O}(80: 20, \mathrm{v} / \mathrm{v})$. The study of the same cations described before in

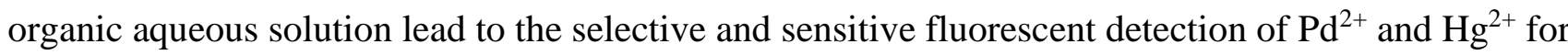
receptor 3. Due to insolubility problems it was not possible to perform the same studies with compounds $\mathbf{4 a - b}$. For compound $\mathbf{3}$, the number of necessary metal equivalents to achieve a plateau was between 20 to $\mathrm{Pd}^{2+}$ and 40 equivalents for $\mathrm{Hg}^{2+}$ (Figure 7).
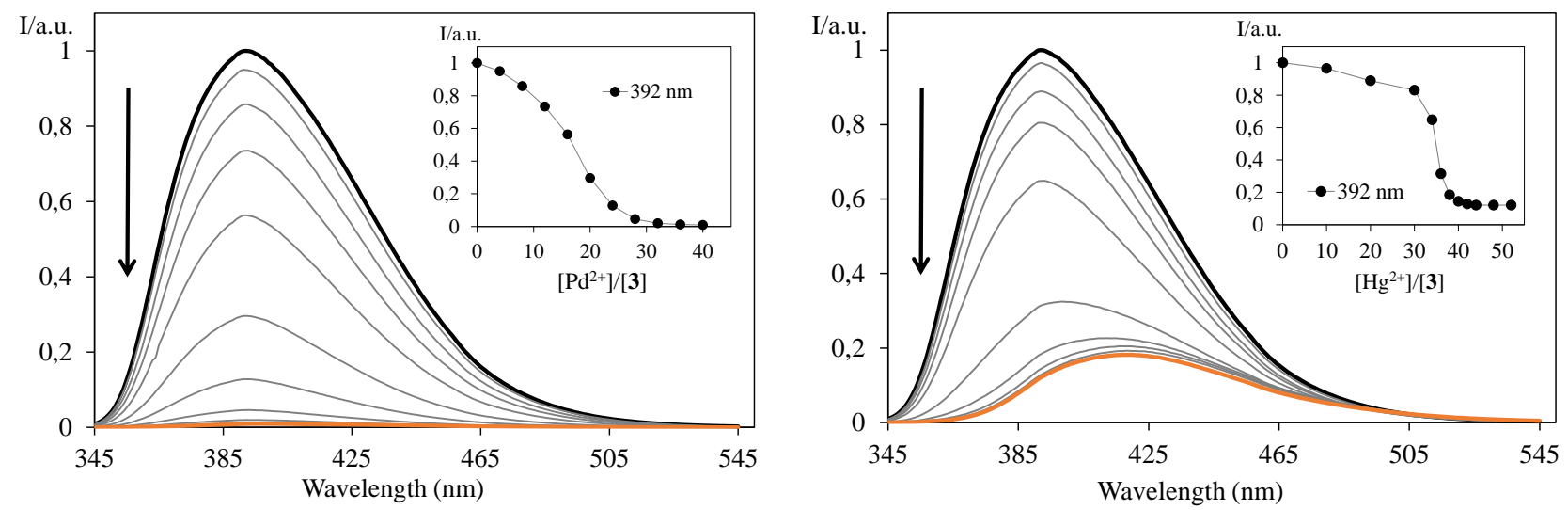

Figure 7. Spectrofluorimetric titration of compound 3 in the presence of $\left[\mathrm{Pd}\left(\mathrm{CH}_{3} \mathrm{CN}\right)_{4}\left(\mathrm{BF}_{4}\right)_{2}\right]($ left $)$ and $\left[\mathrm{Hg}\left(\mathrm{ClO}_{4}\right)_{2} \cdot 3 \mathrm{H}_{2} \mathrm{O}\right]$ (right), in acetonitrile/ $\mathrm{H}_{2} \mathrm{O}(80: 20)\left([3]=1.0 \times 10^{-5} \mathrm{M}, \mathrm{T}=298 \mathrm{~K}, \lambda_{\mathrm{exc}}=325\right.$ $\mathrm{nm})$. Inset: normalised emission at $392 \mathrm{~nm}$ as a function of added metal equivalents. 


\section{4. ${ }^{1} \mathrm{H}$ NMR titration for compound 3}

${ }^{1} \mathrm{H}$ NMR spectroscopy was used to investigate the nature of cation coordination, and experiments were carried out in acetonitrile- $d_{3}$. A ${ }^{1} \mathrm{H}$ NMR titration using firstly $\mathrm{Ca}^{2+}$, followed by paramagnetic $\mathrm{Cu}^{2+}$ was performed. In more detail, the addition of $\mathrm{Ca}^{2+}$ promoted remarkable shifts only in the crown ether $\mathrm{CH}_{2}$ protons. All the signals of the $\mathrm{CH}_{2}$ protons, initially appearing at about 3.65-4.15 ppm were shifted downfield to $3.82-4.35 \mathrm{ppm}$ and became broader during the addition of $\mathrm{Ca}^{2+}$ until 4.0 equivalents. The subsequent addition of 1.0 equivalent of $\mathrm{Cu}^{2+}$ resulted in slight downfield shifts for the aromatic protons signals, becoming broader with overlapping of some signals (Figure 8). This experiment corroborated the different coordination sites suggested for the complexation pathway (see also figure 6).

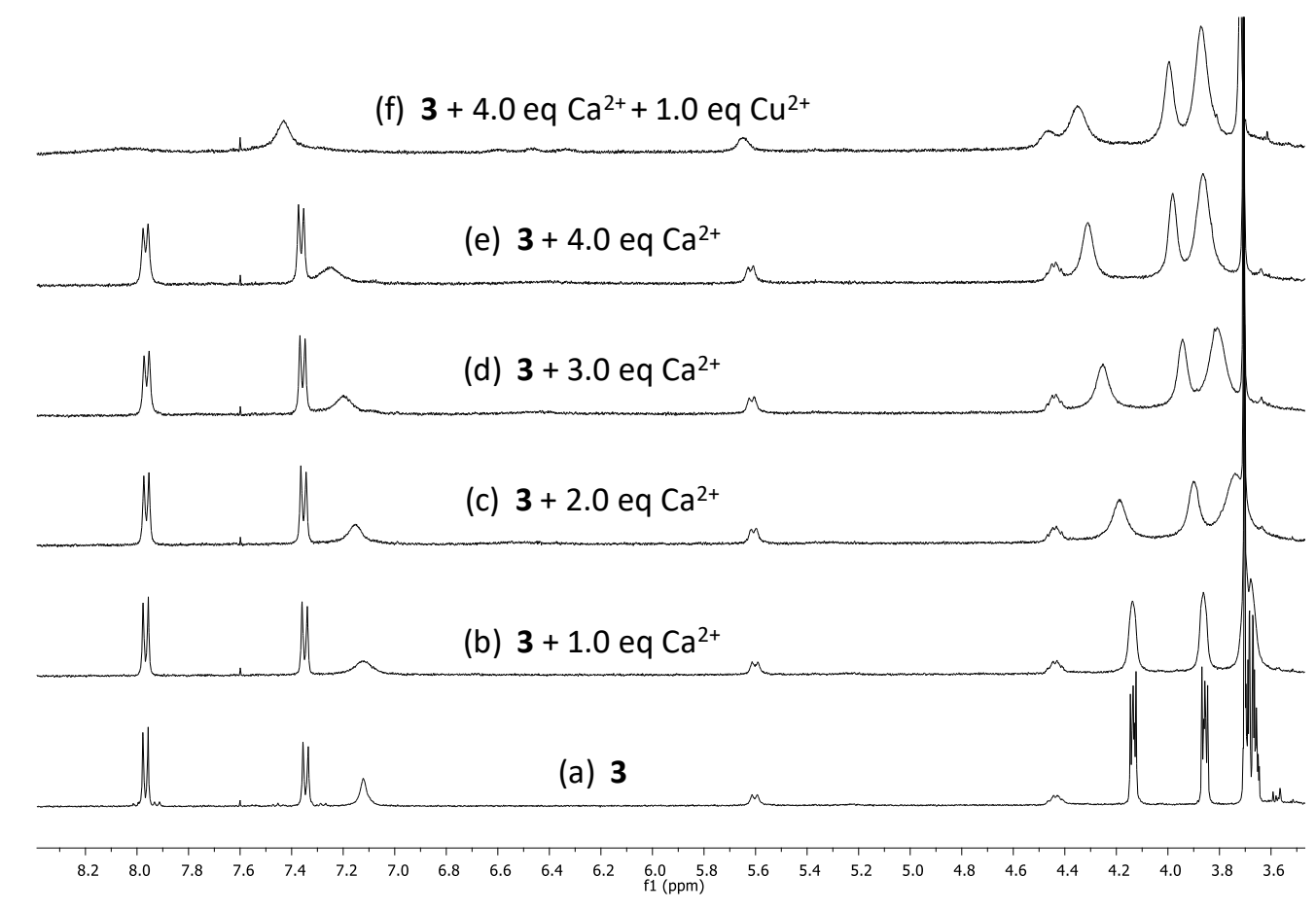

Figure 8. Partial ${ }^{1} \mathrm{H}$ NMR spectra of compound $3\left(7.1 \times 10^{-2} \mathrm{M}\right)$ in acetonitrile- $d_{3}$ in (a) the absence and (b) the presence of 1.0, (c) 2.0, (d) 3.0, (e) 4.0 equivalents of $\mathrm{Ca}^{2+}$ and (f) 1.0 equivalents of $\mathrm{Cu}^{2+}$.

The association constants of compounds $\mathbf{3}$ and $\mathbf{4 a - b}$ with the various cations were obtained from the spectroscopic titrations using the Hyperquad program (Table 4) [12]. For compound 3, the suggested metal to ligand (M:L) stoichiometry for all cations is $1: 1$, whereas for compounds $\mathbf{4 a - b}$ is 1:2. 
Table 4. Logarithm of the association constants ( $\left.K_{\text {ass }}\right)$ for the interaction of phenylalanines 3-4 with several cations in acetonitrile (M:L stoichiometry is $1: 1$ for $\mathbf{3}$ and 1:2 for $\mathbf{4 a - b}$ ).

\begin{tabular}{|c|c|c|c|}
\hline \multirow{2}{*}{ Cation } & \multicolumn{3}{|c|}{$\log K_{\text {ass }}$} \\
\hline & 3 & $4 \mathbf{a}$ & $4 b$ \\
\hline $\mathrm{Cu}^{2+}$ & $7.800 \pm 0.012$ & $10.86 \pm 0.22$ & $12.91 \pm 0.17$ \\
\hline $\mathrm{Cd}^{2+}$ & $3.665 \pm 0.011$ & $\mathrm{a}$ & $16.33 \pm 0.30$ \\
\hline $\mathrm{Co}^{2+}$ & $3.571 \pm 0.011$ & $7.947 \pm 0.014$ & $16.02 \pm 0.65$ \\
\hline $\mathrm{Ca}^{2+}$ & $\mathrm{a}$ & $11.70 \pm 0.23$ & $14.73 \pm 0.46$ \\
\hline $\mathrm{Pd}^{2+}$ & $7.488 \pm 0.025$ & $11.17 \pm 0.55$ & $12.29 \pm 0.40$ \\
\hline $\mathrm{Fe}^{2+}$ & $4.776 \pm 0.005$ & $13.27 \pm 0.87$ & $13.53 \pm 0.24$ \\
\hline $\mathrm{Fe}^{3+}$ & $7.246 \pm 0.030$ & $10.74 \pm 0.42$ & $12.30 \pm 0.24$ \\
\hline $\mathrm{Ni}^{2+}$ & $5.495 \pm 0.088$ & $11.54 \pm 0.24$ & a \\
\hline $\mathrm{Zn}^{2+}$ & $3.400 \pm 0.048$ & $11.84 \pm 0.22$ & $13.66 \pm 0.23$ \\
\hline $\mathrm{Hg}^{2+}$ & $7.371 \pm 0.048$ & $11.66 \pm 0.25$ & $12.21 \pm 0.18$ \\
\hline $\mathrm{Na}^{+}$ & a & $12.49 \pm 0.38$ & $16.83 \pm 0.91$ \\
\hline $\mathrm{Cr}^{3+}$ & $6.858 \pm 0.085$ & $11.08 \pm 0.35$ & $15.98 \pm 0.74$ \\
\hline
\end{tabular}

${ }^{\mathrm{a}}$ No reliable results were obtained.

\section{Conclusions}

Compounds 3-4 were synthesized in moderate to good yields (39-70\%) using several synthetic methodologies.

The different crown ether binding moieties as well as the electronic nature and the length of the $\pi$ bridge linked to the benzimidazole allowed the tuning of the sensory properties as seen by spectrofluorimetric titrations, in acetonitrile and acetonitrile/ $\mathrm{H}_{2} \mathrm{O}$. Therefore, benzocrown ether amino acid 3 is a fluorimetric chemosensor, being selective and sensitive for $\mathrm{Cu}^{2+}$ and $\mathrm{Pd}^{2+}$ in aqueous 
solutions (acetonitrile/ $\mathrm{H}_{2} \mathrm{O} ; 80: 20$ ). On the other hand, the metal cation sensing properties displayed by compound 4a bearing an arylthienyl spacer showed that this is a promising candidate as fluorimetric chemosensor for $\mathrm{Fe}^{3+}, \mathrm{Pb}^{2+}$ and $\mathrm{Pd}^{2+}$ in acetonitrile solution. Compound $\mathbf{4 b}$ functionalized with the 4'amino-5'-nitrobenzo-18-crown-6 exhibited a decrease of selectivity since a complete fluorescence quenching or a 80-90\% quenching of fluorescence was achieved for several cations $\left(\mathrm{Co}^{2+}, \mathrm{Cu}^{2+} \mathrm{Fe}^{3+}\right.$, $\mathrm{Hg}^{2+}, \mathrm{Pd}^{2+}, \mathrm{Cd}^{2+}, \mathrm{Cr}^{3+}$ and $\left.\mathrm{Fe}^{2+}\right)$.

\section{Acknowledgements}

Thanks are due to Fundação para a Ciência e Tecnologia (Portugal) for financial support to the Portuguese NMR network (PTNMR, Bruker Avance III 400-Univ. Minho), FCT and FEDER (European Fund for Regional Development)-COMPETEQREN-EU for financial support to the research centre CQ/UM [PEst-C/QUI/UI0686/2013 (FCOMP-01-0124-FEDER-037302], a PhD grant to C.I.C. Esteves (SFRH/BD/68360/2010) and a post-doctoral grant to R.M.F. Batista (SFRH/BPD/79333/2011).

\section{References}

[1] a) Prodi L, Bolletta F, Montalti M, Zaccheroni N. Luminescent chemosensors for transition metal ions. Coord Chem Rev 2000;205:59-83;

b) Gale PA. Anion and ion-pair receptor chemistry: highlights from 2000 and 2001. Coord Chem Rev 2003;240:191-221.

c) Martínez-Manêz R, Sancenón F. Fluorogenic and chromogenic chemosensors and reagents for anions. Chem Rev 2003;103:4419-4476;

d) Callan JF, de Silva AP, Magri DC. Luminescent sensors and switches in the early 21 st century. Tetrahedron 2005;61:8551-8588;

e) Formica M, Fusi V, Giorgi L, Micheloni M. New fluorescent chemosensors for metal ions in solution. Coord Chem Rev 2012;256:170-192;

f) Santos-Figueroa LE, Moragues ME, Climent E, Agostini A, Martínez-Máñez R, Sancenón F. Chromogenic and fluorogenic chemosensors and reagents for anions. A comprehensive review of the years 2010-2011. Chem Soc Rev 2013;42:3489-3613.

[2] a) Zhang M, Li M, Zhao Q, Li F, Zhang D, Zhang J, et al. Novel Y-type two-photon active fluorophore: synthesis and application in fluorescent sensor for cysteine and homocysteine. Tetrahedron Lett 2007;48:2329-2333; 
b) Zhang M, Li MY, Li FY, Cheng YF, Zhang JP, Yi T, et al. A novel Y-type, two-photon active fluorophore: Synthesis and application in ratiometric fluorescent sensor for fluoride anion. Dyes Pigments 2008;77:408-414;

c) Molina P, Tárraga A, Oton F. Imidazole derivatives: A comprehensive survey of their recognition properties. Org Biomol Chem 2012;10:1711-1724.

[3] a) Gokel GW, Leevy WM, Weber ME. Crown ethers: Sensors for ions and molecular scaffolds for materials and biological models. Chem Rev 2004;104:2723-2750;

b) Fery-Forgues S, Al-ali F. Bis(azacrown ether) and bis(benzocrown ether) dyes: butterflies, tweezers and rods in cation binding. J Photochem Photobiol C 2004;5:139-153.

[4] a) Batista RMF, Oliveira E, Costa SPG, Lodeiro C, Raposo MMM. Synthesis and evaluation of bipendant-armed (oligo)thiophene crown ether derivatives as new chemical sensors. Tetrahedron Lett 2008;49:6575-6578;

b) Pedras B, Fernandes L, Oliveira E, Rodríguez L, Raposo MMM, Capelo JL, Lodeiro C. Synthesis, characterization and spectroscopic studies of two new schiff-base bithienyl pendantarmed 15-crown-5 molecular probes. Inorg Chem Commun 2009;12:79-85;

c) Oliveira E, Batista RMF, Costa SPG, Lodeiro C, Raposo MMM. Exploring the emissive properties of new azacrown compounds bearing aryl, furyl, or thienyl moieties: a special case of chelation enhancement of fluorescence upon interaction with $\mathrm{Ca}^{2+}, \mathrm{Cu}^{2+}$ or $\mathrm{Ni}^{2+}$. Inorg Chem 2010;49:10847-10857;

d) Batista RMF, Oliveira E, Costa SPG, Lodeiro C, Raposo MMM. (Oligo)thienyl-imidazobenzocrown ether derivatives: Synthesis, photophysical studies and evaluation of their chemosensory properties. Talanta 2011;85:2470-2478;

e) Batista RMF, Oliveira E, Costa SPG, Lodeiro C, Raposo MMM. Imidazo-benzo-15-crown-5 ethers bearing arylthienyl and bithienyl moieties as novel fluorescent chemosensors for $\mathrm{Pd}^{2+}$ and $\mathrm{Cu}^{2+}$. Tetrahedron 2011;67:7106-7113.

[5] a) Zhu L, Zhang L, Younes AH. Fluorescent heteroditopic ligands of metal ions. Supramol Chem 2009;21:268-283.

(b) Alfonso M, Sola A, Caballero A, Tárraga A, Molina P. Heteroditopic ligands based on ferrocenyl benzimidazoles fused to an additional diaza heterocyclic ring system. Dalton Trans 2009;9653-9658.

[6] a) Esteves CIC, Silva AMF, Raposo MMM, Costa SPG. Unnatural benz-X-azolyl asparagine derivatives as novel fluorescent amino acids: synthesis and photophysical characterization. Tetrahedron 2009;65:9373-9377; 
b) Esteves CIC, Raposo MMM, Costa SPG. Synthesis and evaluation of benzothiazolyl and benzimidazolyl asparagines as amino acid based selective fluorimetric chemosensors for $\mathrm{Cu}^{2+}$. Tetrahedron 2010;66:7479-7486;

c) Esteves CIC, Raposo MMM, Costa SPG. Novel highly emissive non proteinogenic amino acids: synthesis of 1,3,4-thiadiazolyl asparagines and evaluation as fluorimetric chemosensors for biologically relevant transition metal cations. Amino Acids 2011;40:1065-1075;

d) Costa SPG, Oliveira E, Lodeiro C, Raposo MMM. Synthesis, characterization and metal ion detection of novel fluoroionophores based on heterocyclic substituted alanines. Sensors 2007;7:2096-2114,

e) Oliveira E, Genovese D, Juris R, Zaccheroni N, Capelo JL, Raposo MMM, Costa SPG, Prodi

L, Lodeiro C. Bioinspired systems for metal-ion sensing: new emissive peptide probes based on benzo[d]oxazole derivatives and their gold and silica nanoparticles. Inorg Chem 2011;50: 88348849.

[7] Morris JV, Mahaney MA, Huber JR. Fluorescence quantum yield determinations - 9,10diphenylanthracene as a reference-standard in different solvents. J Phys Chem 1976;80:969-974.

[8] a) Morera E, Ortar G, Varani A. An improved preparation of 4-hydroxymethyl-L-phenylalanine. Synth Commun 1998;28:4279-4285;

b) Shieh W-C, Carlson JA. A simple asymmetric-synthesis of 4-arylphenylalanines via palladiumcatalyzed cross-coupling reaction of arylboronic acids with tyrosine triflate. J Org Chem 1992;57:379-381.

[9] Costa SPG, Oliveira E, Lodeiro C, Raposo MMM. Heteroaromatic alanine derivatives bearing (oligo)thiophene units: synthesis and photophysical properties. Tetrahedron Lett 2008;49:52585261.

[10] a) Kamlet MJ, Abboud JL, Taft RW. The solvatochromic comparison method. 6 . The pi* scale of solvent polarities. J Am Chem Soc 1977; 99:6027-38;

(b) Kamlet MJ, Abboud JLM, Abraham MH, Taft RW. Linear solvation energy relationships 23. A comprehensive collection of the solvatochromic parameters, $\mathrm{pi}^{*}$, alpha, and beta, and some methods for simplifying the generalized solvatochromic equation. J Org Chem 1983;48:2877.

[11] Valeur B. Molecular fluorescence: Principles and applications. Wiley-VCH Verlag GmbH; 2001.

[12] Gans P, Sabatini A, Vacca A. Investigation of equilibria in solution. Determination of equilibrium constants with the HYPERQUAD suite of programs. Talanta 1996;43:1739-1753. 


\section{Supporting Information}

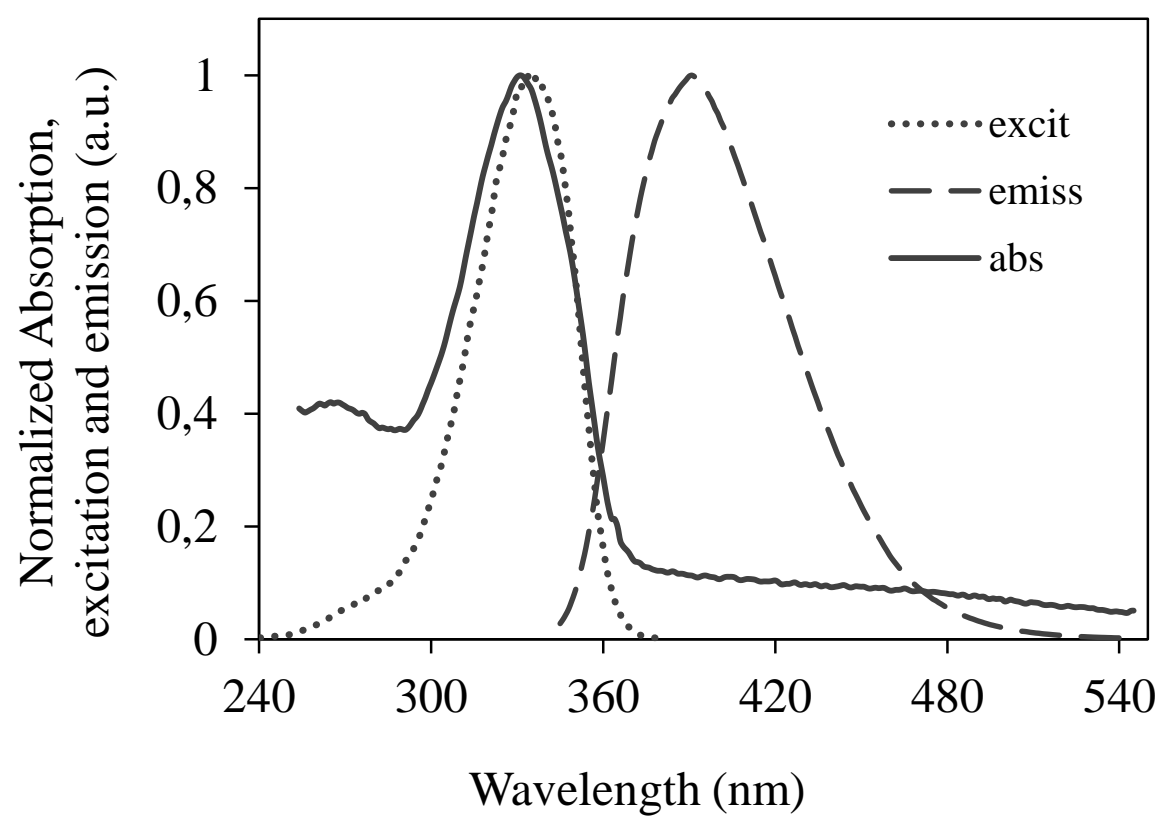

Figure S1. Absorption, emission and excitation spectra of compound 3 in $\mathrm{ACN} / \mathrm{H}_{2} \mathrm{O}$ (80:20) solution.

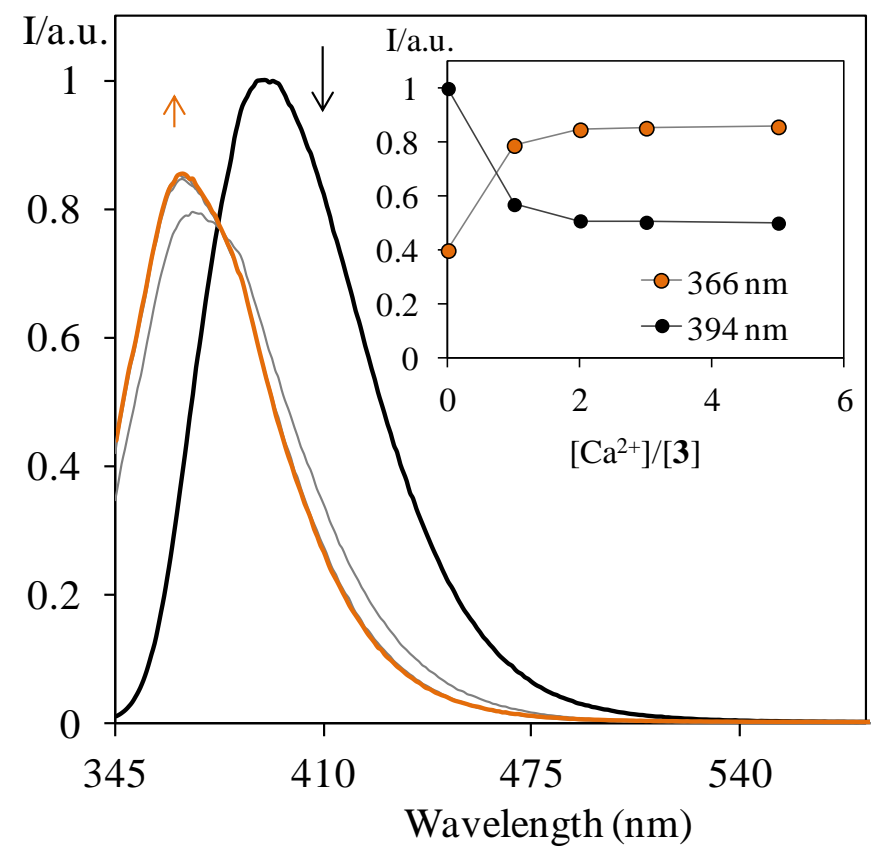

Figure S2. Spectrofluorimetric titrations of compound $\mathbf{3}$ in the presence of $\mathrm{Ca}^{2+}$, in acetonitrile solution. ([3] $=10 \mu \mathrm{M}, \mathrm{T}=298 \mathrm{~K}, \lambda_{\mathrm{exc}}=325 \mathrm{~nm}$ ). Inset: normalised emission at $366 \mathrm{~nm}$ and $394 \mathrm{~nm}$ as a function of added metal equivalents. 


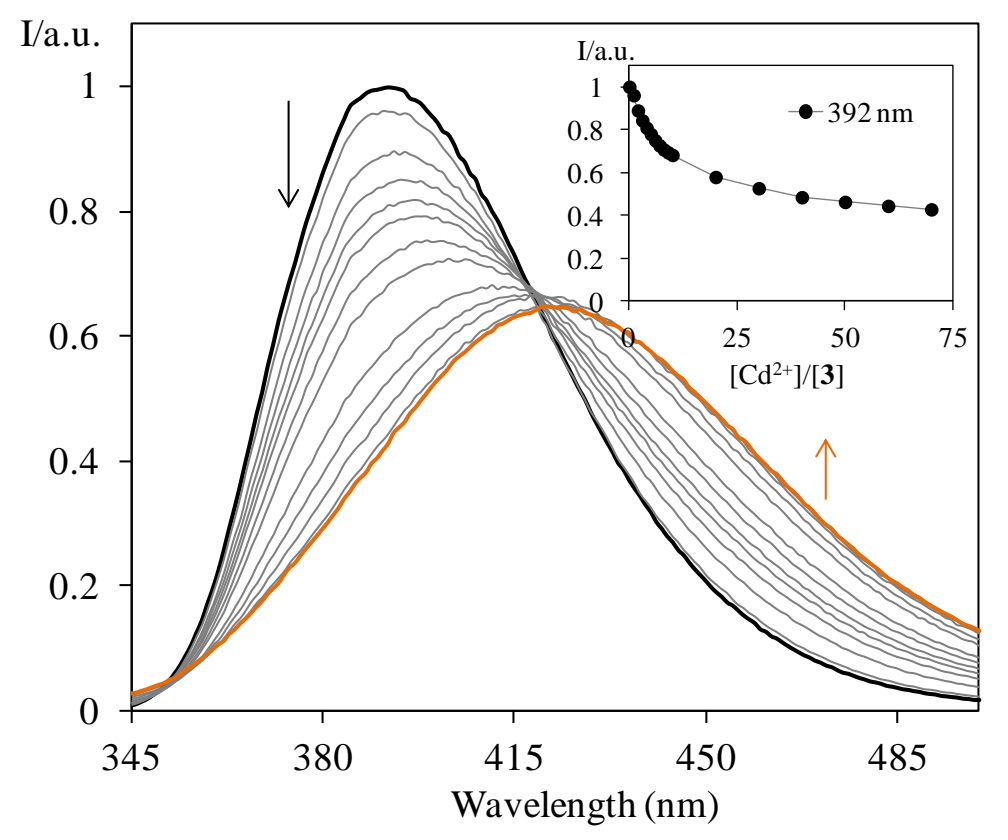

Figure S3. Spectrofluorimetric titrations of compound $\mathbf{3}$ in the presence of $\mathrm{Cd}^{2+}$, in acetonitrile solution. ([3] $=10 \mu \mathrm{M}, \mathrm{T}=298 \mathrm{~K}, \lambda_{\mathrm{exc}}=325 \mathrm{~nm}$ ). Inset: normalised emission at $392 \mathrm{~nm}$ as a function of added metal equivalents.

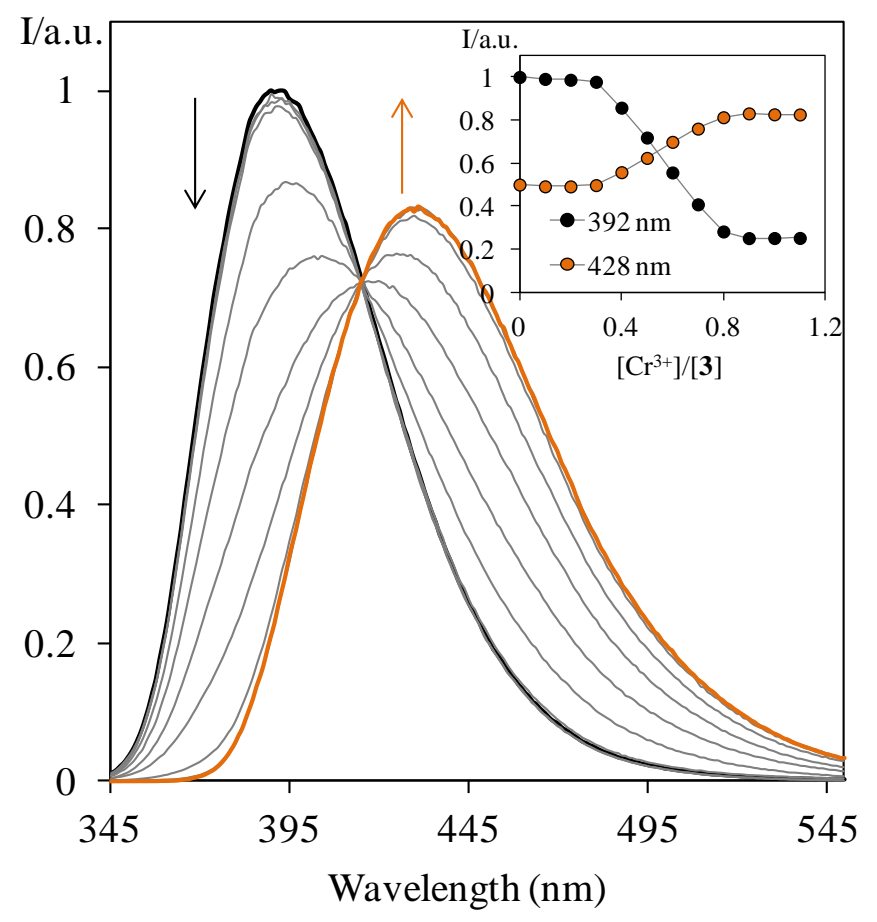

Figure S4. Spectrofluorimetric titrations of compound 3 in the presence of $\mathrm{Cr}^{3+}$, in acetonitrile solution. ([3] $=10 \mu \mathrm{M}, \mathrm{T}=298 \mathrm{~K}, \lambda_{\mathrm{exc}}=325 \mathrm{~nm}$ ). Inset: normalised emission at $392 \mathrm{~nm}$ and $428 \mathrm{~nm}$ as a function of added metal equivalents. 


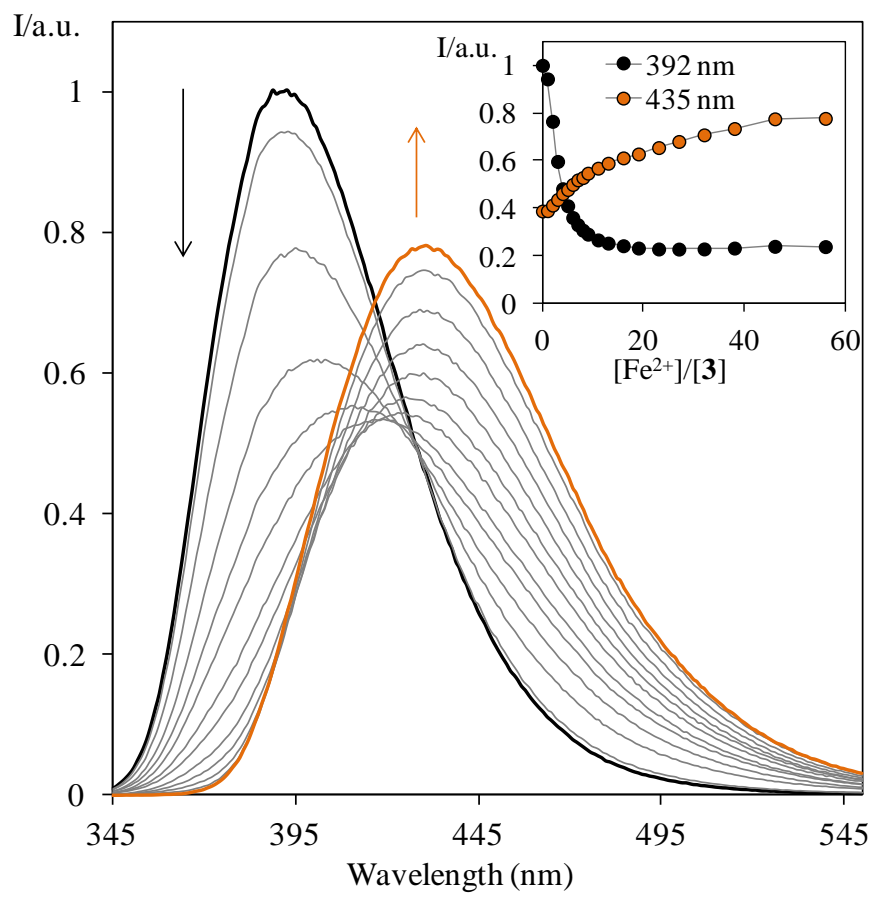

Figure S5. Spectrofluorimetric titrations of compound 3 in the presence of $\mathrm{Fe}^{2+}$, in acetonitrile solution. ([3] $=10 \mu \mathrm{M}, \mathrm{T}=298 \mathrm{~K}, \lambda_{\mathrm{exc}}=325 \mathrm{~nm}$ ). Inset: normalised emission at $392 \mathrm{~nm}$ and $435 \mathrm{~nm}$ as a function of added metal equivalents.

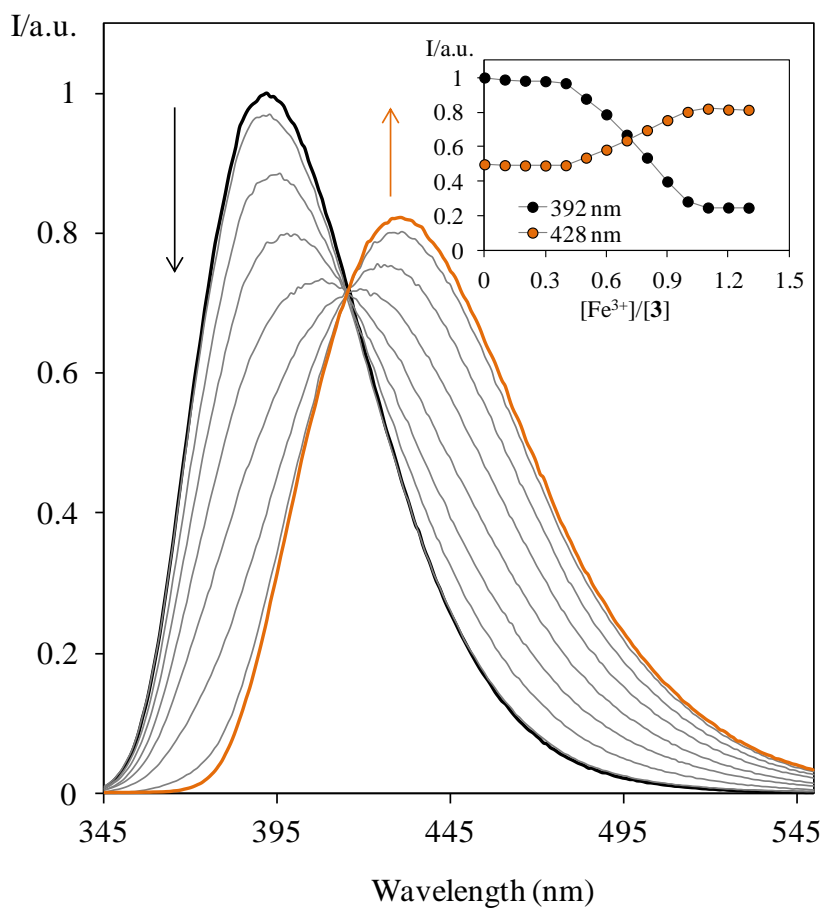

Figure S6. Spectrofluorimetric titrations of compound 3 in the presence of $\mathrm{Fe}^{3+}$, in acetonitrile solution. ([3] $=10 \mu \mathrm{M}, \mathrm{T}=298 \mathrm{~K}, \lambda_{\mathrm{exc}}=325 \mathrm{~nm}$ ). Inset: normalised emission at $392 \mathrm{~nm}$ and $428 \mathrm{~nm}$ as a function of added metal equivalents. 


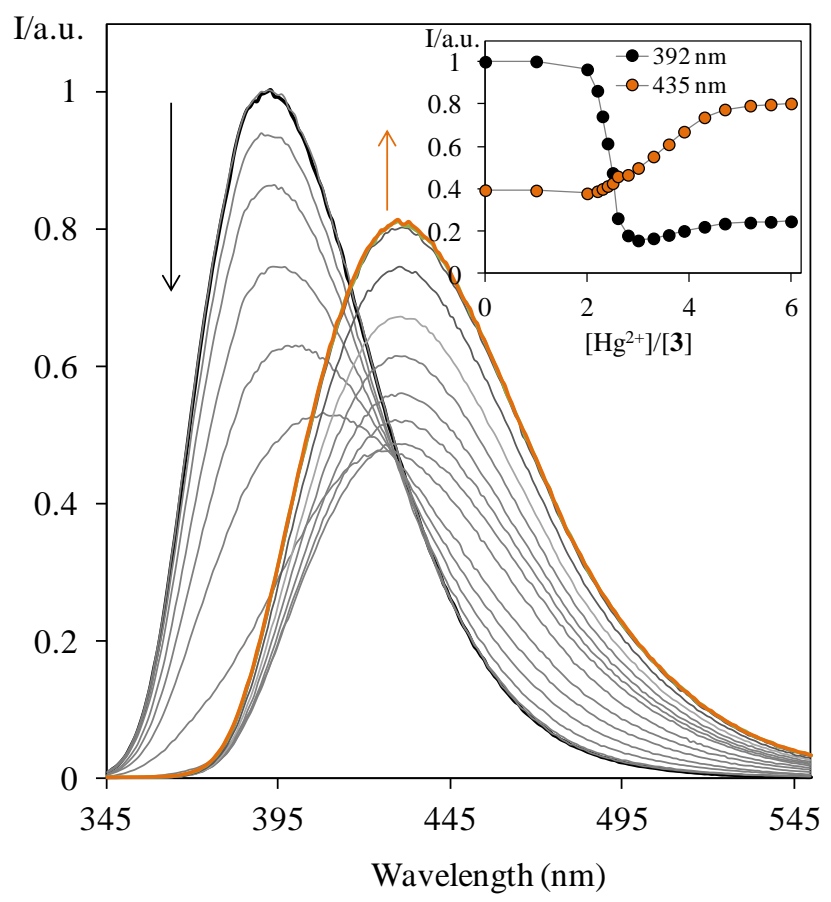

Figure S7. Spectrofluorimetric titrations of compound 3 in the presence of $\mathrm{Hg}^{2+}$, in acetonitrile solution. $\left([3]=10 \mu \mathrm{M}, \mathrm{T}=298 \mathrm{~K}, \lambda_{\mathrm{exc}}=325 \mathrm{~nm}\right)$. Inset: normalised emission at $392 \mathrm{~nm}$ and $435 \mathrm{~nm}$ as a function of added metal equivalents.

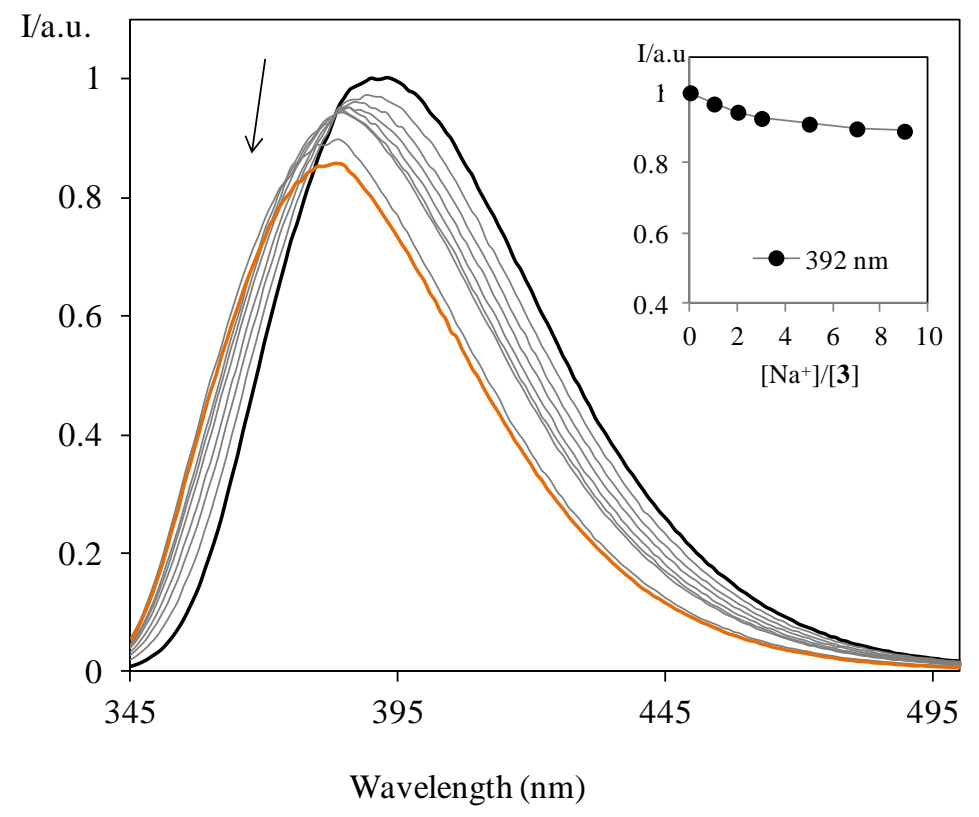

Figure S8. Spectrofluorimetric titrations of compound 3 in the presence of $\mathrm{Na}^{+}$, in acetonitrile solution. $\left([3]=10 \mu \mathrm{M}, \mathrm{T}=298 \mathrm{~K}, \lambda_{\mathrm{exc}}=325 \mathrm{~nm}\right.$ ). Inset: normalised emission at $392 \mathrm{~nm}$ as a function of added metal equivalents. 


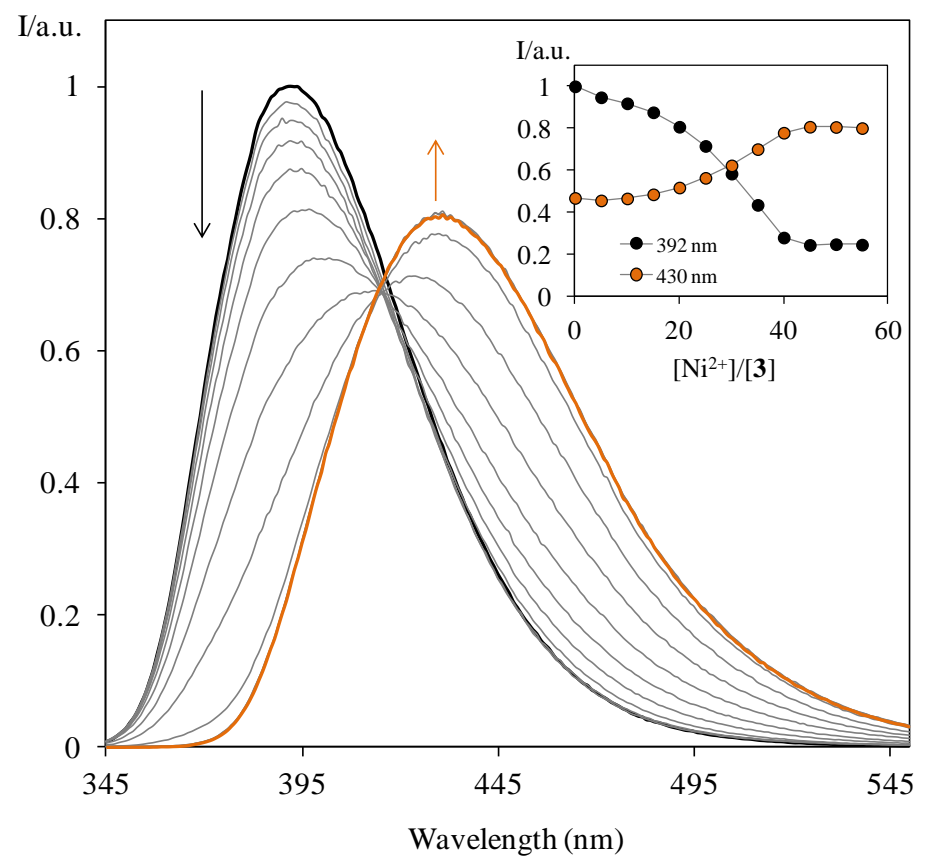

Figure S9. Spectrofluorimetric titrations of compound $\mathbf{3}$ in the presence of $\mathrm{Ni}^{2+}$, in acetonitrile solution. ([3] $=10 \mu \mathrm{M}, \mathrm{T}=298 \mathrm{~K}, \lambda_{\mathrm{exc}}=325 \mathrm{~nm}$ ). Inset: normalised emission at $392 \mathrm{~nm}$ and $430 \mathrm{~nm}$ as a function of added metal equivalents.

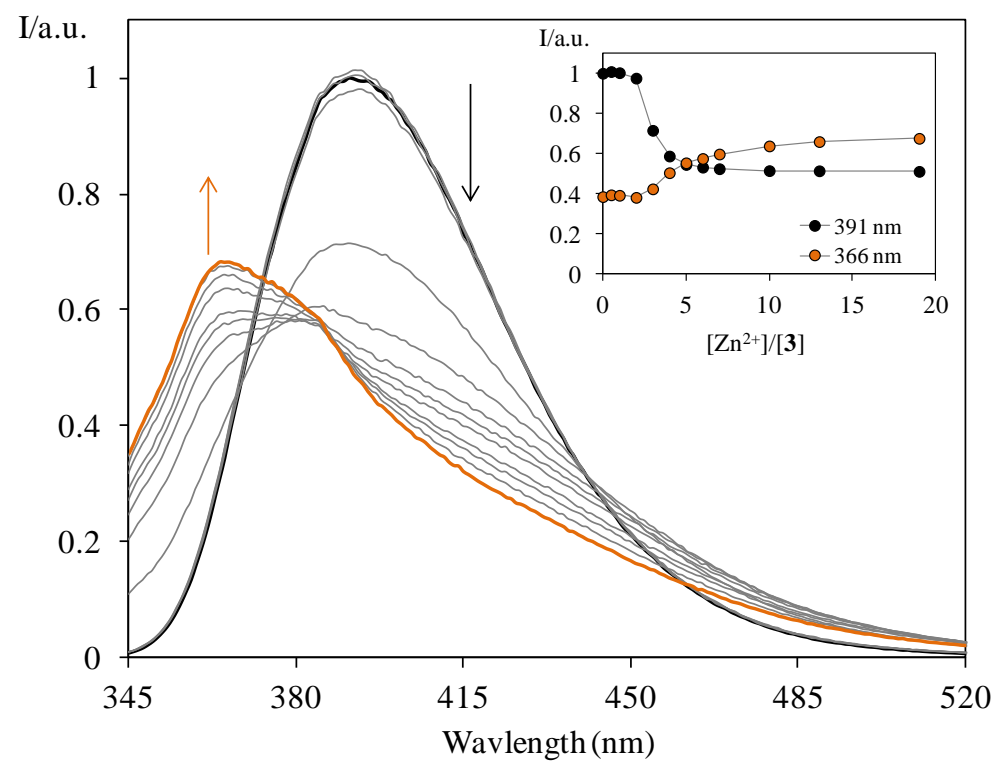

Figure S10. Spectrofluorimetric titrations of compound 3 in the presence of $\mathrm{Zn}^{2+}$, in acetonitrile solution. ([3] $=10 \mu \mathrm{M}, \mathrm{T}=298 \mathrm{~K}, \lambda_{\mathrm{exc}}=325 \mathrm{~nm}$ ). Inset: normalised emission at $391 \mathrm{~nm}$ and $366 \mathrm{~nm}$ as a function of added metal equivalents. 


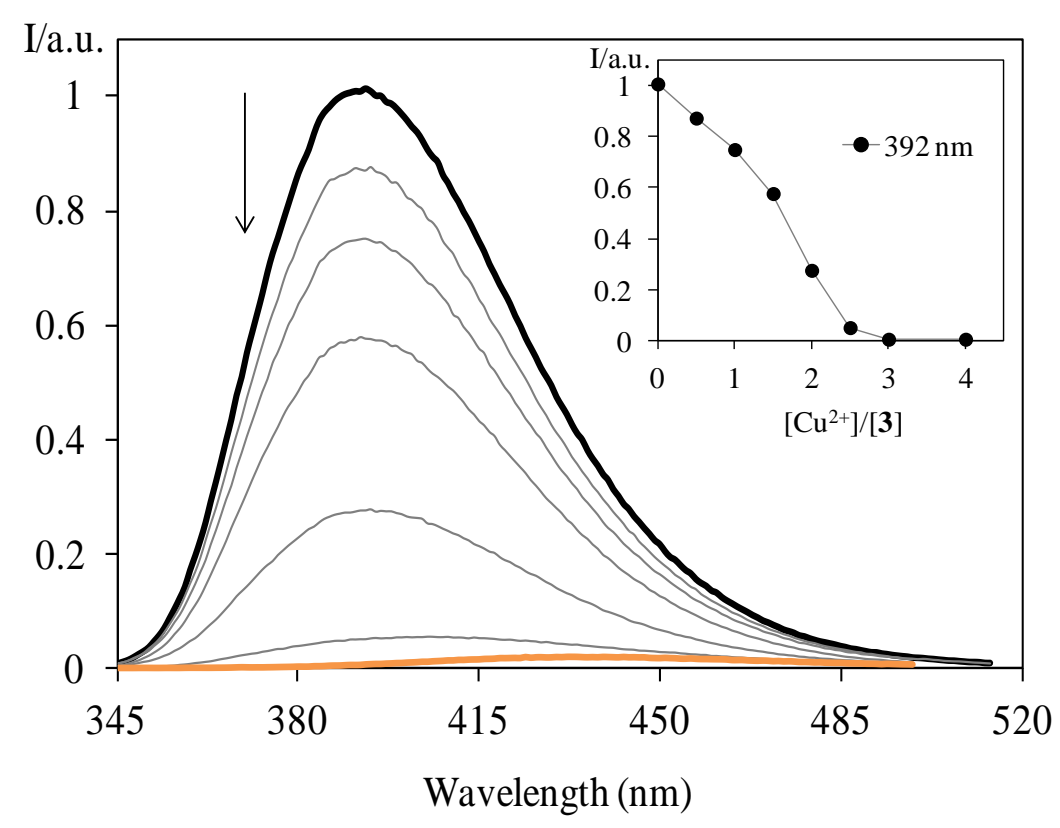

Figure S11. Spectrofluorimetric titrations of compound $\mathbf{3}$ in the presence of $\mathrm{Cu}^{2+}$, in acetonitrile solution. ([3] $=10 \mu \mathrm{M}, \mathrm{T}=298 \mathrm{~K}, \lambda_{\mathrm{exc}}=325 \mathrm{~nm}$ ). Inset: normalised emission at $392 \mathrm{~nm}$ as a function of added metal equivalents. 